\title{
Ecological and molecular characterization of a coral black band disease outbreak in the Red Sea during a bleaching event
}

\author{
Ghaida Hadaidi $^{1}$, Maren Ziegler $^{1}{ }^{\text {, Amanda Shore-Maggio }}{ }^{2}$, Thor Jensen $^{1}{ }^{\text {, }}$ Greta Aeby ${ }^{3}$, Christian R \\ Voolstra Corresp. 1 \\ ${ }^{1}$ Red Sea Research Center, Division of Biological and Environmental Science and Engineering (BESE), King Abdullah University of Science and Technology \\ (KAUST), Thuwal, Saudi Arabia \\ 2 Institute of Marine and Environmental Technology (IMET), University of Maryland, Baltimore County, Baltimore, Maryland, United States of America \\ 3 Hawai'i Institute of Marine Biology, Kāne'ohe, Hawaii, United States of America \\ Corresponding Author: Christian R Voolstra \\ Email address: christian.voolstra@kaust.edu.sa
}

Black Band Disease (BBD) is a widely distributed and destructive coral disease that has been studied on a global scale, but baseline data on coral diseases is missing from many areas of the Arabian Seas. Here we report on the broad distribution and prevalence of BBD in the Red Sea in addition to documenting a bleaching-associated outbreak of BBD with subsequent microbial community characterization of BBD microbial mats at this reef site in the southern central Red Sea. Coral colonies with BBD were found at roughly a third of our 22 survey sites with an overall prevalence of $0.04 \%$. Nine coral genera were infected including Astreopora, Coelastrea, Dipsastraea, Gardineroseris, Goniopora, Montipora,Pavona, Platygyra, and Psammocora. For a southern central Red Sea outbreak site, overall prevalence was 40 times higher than baseline (1.7\%). Differential susceptibility to BBD was apparent among coral genera with Dipsastraea(prevalence 6.1 $\%$ ) having more diseased colonies than was expected based on its abundance within transects. Analysis of the microbial community associated with the BBD mat showed that it is dominated by a consortium of cyanobacteria and heterotrophic bacteria. We detected the three main indicators for BBD (filamentous cyanobacteria, sulfate-reducing bacteria (SRB), and sulfide-oxidizing bacteria (SOB)), with high similarity to BBD-associated microbes found worldwide. More specifically, the microbial consortium of BBD-diseased coral colonies in the Red Sea consisted of Oscillatoriasp. (cyanobacteria), Desulfovibriosp. (SRB), and Arcobactersp. (SOB). Given the similarity of associated bacteria worldwide, our data suggest that BBD represents a global coral disease with predictable etiology. Further, we provide a baseline assessment of BBD disease prevalence in the Red Sea, a still understudied region. 
1 Ecological and molecular characterization of a coral black band disease outbreak in the

2 Red Sea during a bleaching event

3

4 G. Hadaidi'; M. Ziegler ${ }^{1}$; A. Shore-Maggio ${ }^{2}$; T. Jensen ${ }^{1}$; G. Aeby ${ }^{3 *}$, C.R. Voolstra ${ }^{*}$

$6 \quad{ }^{1}$ Red Sea Research Center, Division of Biological and Environmental Science and Engineering

7 (BESE), King Abdullah University of Science and Technology (KAUST), Thuwal, Saudi Arabia

8

9 2Institute of Marine and Environmental Technology (IMET), University of Maryland, Baltimore

10 County, Baltimore, Maryland, United States of America

11

$12{ }^{3} H_{a w a i}$ i Institute of Marine Biology, Kāne'ohe, Hawaii, United States of America

13

$14 *$ Corresponding authors

15 Contact information:

16 Email: greta@hawaii.edu and christian.voolstra@kaust.edu.sa

17 Tel: +966 128082377

18

19 Running title: Black band disease in Red Sea corals

20 


\section{Abstract}

22 Black Band Disease (BBD) is a widely distributed and destructive coral disease that has been 23 studied on a global scale, but baseline data on coral diseases is missing from many areas of the 24 Arabian Seas. Here we report on the broad distribution and prevalence of BBD in the Red Sea in 25 addition to documenting a bleaching-associated outbreak of BBD with subsequent microbial 26 community characterization of BBD microbial mats at this reef site in the southern central Red

27 Sea. Coral colonies with BBD were found at roughly a third of our 22 survey sites with an 28 overall prevalence of $0.04 \%$. Nine coral genera were infected including Astreopora, Coelastrea, 29 Dipsastraea, Gardineroseris, Goniopora, Montipora, Pavona, Platygyra, and Psammocora. For 30 a southern central Red Sea outbreak site, overall prevalence was 40 times higher than baseline 31 (1.7\%). Differential susceptibility to BBD was apparent among coral genera with Dipsastraea 32 (prevalence $6.1 \%$ ) having more diseased colonies than was expected based on its abundance 33 within transects. Analysis of the microbial community associated with the BBD mat showed that 34 it is dominated by a consortium of cyanobacteria and heterotrophic bacteria. We detected the 35 three main indicators for BBD (filamentous cyanobacteria, sulfate-reducing bacteria (SRB), and 36 sulfide-oxidizing bacteria (SOB)), with high similarity to BBD-associated microbes found 37 worldwide. More specifically, the microbial consortium of BBD-diseased coral colonies in the Red Sea consisted of Oscillatoria sp. (cyanobacteria), Desulfovibrio sp. (SRB), and Arcobacter sp. (SOB). Given the similarity of associated bacteria worldwide, our data suggest that BBD represents a global coral disease with predictable etiology. Further, we provide a baseline

41 assessment of BBD disease prevalence in the Red Sea, a still understudied region. 


\section{Introduction}

43 The rise of coral disease outbreaks contributes to the decline of coral reefs globally (Cróquer \&

44 Weil 2009; Harvell et al. 2009; Hoegh-Guldberg 2012; McLeod et al. 2010; Randall \& van

45 Woesik 2015) and coral disease appears to be the most destructive factor on many reefs. For

46 instances, the Caribbean has been named a "disease hot spot" due to the fast emergence, high

47 prevalence, and virulence of coral diseases in this region (Rosenberg \& Loya 2013). Coral

48 disease outbreaks in the last decades in the Caribbean have resulted in significant losses in coral

49 cover, diversity, and habitat (Aronson \& Precht 2001; Bruckner 2002; Hughes 1994; Precht et al.

50 2016; Weil 2002). Following the mass-bleaching event in 2005 in the US Virgin islands, coral

51 disease outbreaks reduced coral cover by more than 50 \% (Cróquer \& Weil 2009; Miller et al.

52 2009).

53

54 Coral diseases were first reported in the Caribbean in the 1970s, including black band disease

55 (BBD), which is considered the most studied coral disease due to its widespread occurrence on

56 reefs around the world (Bourne et al. 2011; Richardson 2004). Black band disease has been

57 reported from reefs throughout the Caribbean, the Indo-pacific regions, the Red Sea, and the

58 Great Barrier Reef (Al-Moghrabi 2001; Dinsdale 2002; Green \& Bruckner 2000; Kaczmarsky

59 2006; Lewis et al. 2017; Montano et al. 2012; Page \& Willis 2006; Sutherland et al. 2004; Weil

60 et al. 2012). BBD is the first described coral disease (Antonius 1973), affecting scleractinian and

61 gorgonian corals (Green \& Bruckner 2000; Sutherland et al. 2004; Weil 2004). BBD prevalence

62 generally is considered low (Dinsdale 2002; Edmunds 1991; Weil 2002); however, this disease is

63 a serious threat to coral reef ecosystems worldwide due to its persistence, leading to coral

64 mortality in the long-term (Bruckner \& Bruckner 1997; Green \& Bruckner 2000; Kaczmarsky

65 2006; Kuta \& Richardson 1996; Page \& Willis 2006; Sutherland et al. 2004; Zvuloni et al. 
66

67

68

69

70

71

72

73

74

75

76

77

78

79

80

81

82

83

84

85

86

87

88

2009). Susceptibility to BBD differs between coral taxa and may result in long-term changes to coral community structure (Bruckner \& Bruckner 1997; Page \& Willis 2006). The abundance of BBD is affected by several environmental factors, including sea water temperature, water depth, solar irradiance, host population diversity, and anthropogenic nutrients (Al-Moghrabi 2001;

Kaczmarsky 2006; Kuta \& Richardson 2002; Montano et al. 2013). Interestingly, seasonal temperatures influence BBD prevalence, with increased virulence during warmer summer months (Richardson \& Kuta 2003; Rützler \& Santavy 1983; Willis et al. 2004) as for example, in the Maldives, where sea surface temperatures above $28^{\circ} \mathrm{C}$ promoted BBD infections (Montano et al. 2013).

75

BBD manifests as a dark band that migrates across the coral colony at a rate of $>1 \mathrm{~cm} /$ day (Richardson 1998) leaving behind bare skeleton. The base of the BBD mat is anoxic and high in sulfide levels, causing damage and necrosis to coral tissue (Ainsworth et al. 2007; Carlton \& Richardson 1995; Richardson et al. 1997). The BBD mat is composed of a polymicrobial consortium, dominated by filamentous cyanobacteria, sulfate-reducing bacteria (SRB), including members of Desulfovibrio spp., sulfide-oxidizing bacteria (SOB) (Beggiatoa spp.), and other heterotrophic bacteria (Cooney et al. 2002; Miller \& Richardson 2011; Sato et al. 2010). As a result of diel light changes, the microbial members of the BBD mat undergo vertical migrations, which causes the harmful microenvironment on top of the coral tissue (Carlton \& Richardson 1995; Miller \& Richardson 2011; Richardson 1996). Oxygen depletion and high sulfide concentrations are produced by SRB, which is lethal to the coral tissues and considered the most important factor in BBD pathogenicity (Glas et al. 2012; Richardson 1996; Richardson et al. 1997; Richardson et al. 2009). Although the functional composition of the BBD mat is 
89 conserved, the diversity of the microbial consortium in BBD differs according to geographic

90 location and coral species (Cooney et al. 2002; Frias-Lopez et al. 2004; Sekar et al. 2006).

91

92 The occurrence of BBD in the Red Sea was first recorded by Antonius (1988) where the severity

93 of BBD was measured from rare to moderate and mostly correllated with elevated temperatures

94 and seawater pollution. However, baseline data on BBD prevalence in the Red Sea is still

95 lacking. To fill this gap, we conducted surveys to determine the distribution and prevalence of

96 BBD across the central Red Sea reefs spanning 4 degrees of latitude. We also detected a

97 bleaching-associated outbreak of BBD on a coral reef in the southern central Red Sea and

98 characterized the microbial community of BBD microbial mats from Coelastrea sp., Dipsastraea

99 sp., Goniastrea sp., and Platygra sp. using high-throughput sequencing. We compared the

100 microbial consortium to that reported from other regions of the world in order to identify

101 biogeographic patterns in the main BBD consortium members.

102 


\section{Material and Methods}

\section{1. Black band disease surveys}

105 Coral community structure and BBD prevalence was recorded at 22 sites spanning approx. 535

$106 \mathrm{~km}$ along the coast of Saudi Arabia in the Red Sea (Fig. 1, Table 1). At least six reefs per region

107 (Yanbu, Thuwal, Al-Lith) were surveyed with three additional reefs in Thuwal and one reef in

108 Jeddah (80 km from Thuwal) that were surveyed as time permitted. The reefs sampled/assessed

109 in this study do not fall under any legislative protection or special designation as a

110 marine/environmental protected area. Under the auspices of KAUST (King Abdullah University

111 of Science and Technology), the Saudi Coastguard Authority issued sailing permits to the sites

112 that include coral collection. At each site, divers counted coral colonies by genera along two

113 replicate belt transects $(25 \mathrm{~m} \mathrm{x} 1 \mathrm{~m})$. At the same time, point-intercept method was used to

114 characterize the substrate at $25 \mathrm{~cm}$ intervals. All corals with BBD lesions were identified along

115 wider $25 \times 6$ m transects and photographed. Depending on depth and time limits, the length of

116 transects were adjusted as necessary. Survey sites ranged in depth between 3 and 7.6 meters and

117 all surveys were conducted from 19 October to 3 November 2015. The diver surveys were used

118 to determine average percent coral cover, coral community composition, and colony densities.

119 Underwater time constraints prevented counting all colonies within the larger 25 x 6 m belts

120 surveyed for disease. Therefore, BBD prevalence was estimated by calculating the average

121 colony density (by genus) within the $25 \times 1 \mathrm{~m}$ transect and then extrapolating the colony counts

122 to the wider $25 \times 6 \mathrm{~m}$ disease survey area and using this as the denominator of prevalence

123 calculations, i.e. (number of colonies with BBD lesions/total number of estimated colonies) *

124 100) (Aeby et al. 2015a). At the outbreak site, diseased coral colonies were so numerous that

125 only $49 \mathrm{~m}^{2}$ of the transect could be surveyed. The frequency of disease occurrence (FOC) was 
126 calculated by dividing the number of sites having corals with BBD lesions by the total number of

127 sites surveyed. A localized BBD outbreak was discovered at one site and a chi-square goodness-

128 of-fit test was used to examine differential distribution of the number of BBD versus healthy

129 colonies among the coral genera affected by the disease. The chi-square test compares the

130 observed vs. expected number of infected colonies based on the abundance of each coral

131 genus in the field. Statistical analysis was performed using JMP statistical software (v. 10.0.2,

132 SAS Institute Inc., Buckinghamshire, UK).

133 2. Sample collection of black band disease microbial mats and 16S rRNA gene sequencing

134 Microbial mats were collected from BBD infected coral genera (1 colony of Coelastrea sp., 2

135 colonies of Dipsastraea sp., 3 colonies of Goniastrea sp., and 1 colony of Platygra sp.) at the

136 site of the observed BBD outbreak (Al-Lith fringing reef 1) in November 2015. Microbial mats

137 were siphoned off the coral surface with Pasteur pipettes and transferred into ziplock bags under

138 water. Sample replication was limited by obtainable coral species on this reef site and

139 environmental conditions.

140 Samples were homogenized using bead-beating via TissuLyser II (Qiagen, Germany) twice for

$14130 \mathrm{sec}$ at $30 \mathrm{~Hz}, 20 \mu \mathrm{l}$ of the homogenate were boiled in sterile Milli-Q water at $99{ }^{\circ} \mathrm{C}$ for $5 \mathrm{~min}$

142 and subsequently $1 \mu \mathrm{l}$ was directly used as PCR template. To amplify the variable region 4 of the

143 16S rRNA gene the following primers were used: $515 \mathrm{~F}$

144 [5'TCGTCGGCAGCGTCAGATGTGTATAAGAGACAGGTGCCAGCMGCCGCGGTAA '3]

145 and $806 \mathrm{RB}$

146 [5'GTCTCGTGGGCTCGGAGATGTGTATAAGAGACAGGGACTACNVGGGTWTCTAAT

147 '3] (Apprill et al. 2015; Caporaso et al. 2012; Kozich et al. 2013). Primer sequences contained

148 sequencing adaptor overhangs (underlined above; Illumina, San Diego, CA, USA). Triplicate 
149 PCRs were performed for all samples with $0.2 \mu \mathrm{M}$ of each primer in a total reaction volume of

$15025 \mu \mathrm{L}$ using the Qiagen Multiplex PCR Kit. The following cycling conditions were used: $95^{\circ} \mathrm{C}$

151 for $15 \mathrm{~min}$, followed by 27 cycles of $94{ }^{\circ} \mathrm{C}$ for $45 \mathrm{~s}, 50{ }^{\circ} \mathrm{C}$ for $60 \mathrm{~s}, 72{ }^{\circ} \mathrm{C}$ for $90 \mathrm{~s}$, and a final

152 extension step of $72{ }^{\circ} \mathrm{C}$ for $10 \mathrm{~min}$. Amplification was checked visually via $1 \%$ agarose gel

153 electrophoresis. Triplicate samples were pooled and cleaned with ExoProStar 1-Step (GE

154 Healthcare, UK). An indexing PCR was performed on the cleaned samples to add Nextera XT

155 indexing and sequencing adaptors (Illumina) following the manufacturer's protocol and followed

156 by sample normalization and library pooling. 16S rRNA gene amplicon libraries were sequenced

157 on the Illumina MiSeq platform using $2 * 300$ bp overlapping paired-end reads with a $10 \%$ phiX

158 control at the KAUST Bioscience Core Laboratory. Sequence data determined in this study are

159 available under (NCBI Bioproject ID: PRJNA436216).

160

\section{3. Sequence data processing and bacterial community analysis}

162 Processing of raw sequence data was conducted in mothur (version 1.36.1; (Schloss et al. 2009).

163 Using the 'make.contigs' command, sequence reads were joined into contigs. Contigs longer

164 than $310 \mathrm{bp}$ and ambiguously called bases were excluded from the analysis. Subsequently,

165 sequences that occurred only once across the entire dataset (singletons) were removed. The

166 number of distinct sequences were identified and counted, and the total number of sequences per

167 sample was determined using the 'count.seqs' command.

168 The remaining sequences were aligned against SILVA database (release 119; (Pruesse et al.

169 2007). Sequences were pre-clustered allowing for up to a $2 \mathrm{nt}$ difference between the sequences

170 (Huse et al. 2010). Chimeras were removed using UCHIME as implemented in mothur (Edgar et

171 al. 2011). Next, sequences were classified with Greengenes database (release gg_13_8_99; 
172 bootstrap = 60; (McDonald et al. 2012), followed by the removal of chloroplast, mitochondria,

173 Archaea, and eukaryote sequences. Further, we found three abundant bacterial families

174 (Dermabacteraceae-Dietziaceae-Brevibacteriaceae) that were present in all disease samples and

175 at high abundance in our negative control. The negative control was a sample containing water as

176 a template for the PCR reaction. As these bacterial families are also known as kit/reagent/lab

177 contaminants, they were excluded from the data set (Salter et al. 2014). Some additional bacterial

178 taxa that were found in high numbers in the negative control with low abundance in coral

179 samples were excluded (Comamonadaceae-Halomonadaceae-Staphylococcaceae). For further

180 analyses, sequences were subsampled to 7,328 sequences per sample, which is the lowest

181 number of sequences in a sample, and then clustered into OTUs (Operational Taxonomic Units)

182 at a $97 \%$ similarity cutoff. Reference sequences for each OTU were determined by the most

183 abundant sequence (Supplemental Data S1). Alpha diversity indices [i.e., Chao1(Chao 1984),

184 Simpson evenness, and Inverse Simpson Index (Simpson 1949)] were calculated as implemented 185 in mothur.

186 For detecting similarity of the three main microbial consortium members in BBD microbial mats

187 to previously reported taxa from other studies, the representative sequences of the most abundant

188 OTUs were BLASTed against the NCBI database (https://blast.ncbi.nlm.nih.gov) using a 98\%

189 similarity cutoff. Subsequently, our sequences were compared to matches of highly similar

190 bacterial taxa by obtaining the respective coral species, their location, and colony health status.

191 Furthermore, low abundant OTUs not previously reported from BBD, but with related properties

192 to SRB, SOB, or Cyanobacteria were also BLASTed against the NCBI database.

193 16S rRNA sequences of SOB and SRB were aligned and neighbor-joining trees were constructed

194 based on Jukes-Cantor model with MAFFT (Katoh et al. 2017; Kuraku et al. 2013). All positions 
195 containing gaps and missing data were excluded and phylogenetic trees were visualized using 196 Archaeopteryx.js. 


\section{Results}

198 1. Distribution and prevalence of black band disease on the Red Sea reefs

199 We identified 30 coral genera within transects across 22 reef sites (Figure 1) with an average 200 density of 16 coral colonies $/ \mathrm{m}^{2}(\mathrm{SE} \pm 1.2)$ and an average coral cover of $43.8 \%(\mathrm{SE} \pm 4.3)$.

201 Colonies with BBD were found at 8 of 22 sites (Table 1, Figure 1). Over all study sites, nine 202 coral genera were infected and include Astreopora, Coelastrea, Dipsastraea, Gardineroseris, 203 Goniopora, Montipora, Pavona, Platygyra, Psammocora. Approximately 74,090 colonies were 204 examined for disease and overall BBD prevalence over all sites was low $(0.04 \%)$ because most 205 sites had no signs of BBD. At the sites where BBD occurred, 7 of the 8 sites had 1 to 2 colonies 206 infected within survey areas (up to $\left.300 \mathrm{~m}^{2}\right)($ avg. prevalence $=0.064 \%)$ and one site had a 207 localized BBD outbreak (Al-Lith fringing reef 1) where 21 infected colonies were found within $20849 \mathrm{~m}^{2}$ of the transect (prevalence $=1.7 \%$ ) and an additional two colonies outside the transect 209 (Table. 1). At this site, 18 coral genera were found within transects, but only nine coral genera 210 exhibited signs of disease suggesting differential BBD susceptibility among coral genera $\left(\mathrm{x}^{2}=\right.$ $21145.67 \mathrm{df}=6, P<0.001)$. Dipsastraea appeared to be the most susceptible (prevalence $=6.1 \%)$ 212 with more diseased colonies than was expected based on its abundance within transects (Table 213 2). Dipsastraea represented $18.6 \%$ of the coral colonies within transects but $68.2 \%$ (15 of 22) 214 of the BBD colonies.

\section{Bacterial community composition of black band disease microbial mats}

217 Besides the ecological survey of BBD prevalence, we investigated the microbial consortium of 218 the BBD mat of corals from the outbreak site in the southern central Red Sea that was also 219 subject to a bleaching event (Al-Lith fringing reef 1). We assessed whether the same bacterial 
220 players are associated with BBD in the Red Sea in comparison to other sites globally. Seven

221 coral BBD microbial mat samples from the outbreak site included 1 colony of Coelastrea sp., 2

222 colonies of Dipsastraea sp., 3 colonies of Goniastrea sp., and 1 colony of Platygra sp., which

223 together yielded 555,093 raw 16S gene sequences with a mean length of $298 \mathrm{bp}$ (Table 3). After

224 quality filtering and exclusion of chimeras and contaminant sequences, we retained 107,613

225 sequences for analysis of the BBD microbial mat microbiome. To assess bacterial community

226 composition, sequences were classified to family level considering bacterial families that

227 comprised $>1 \%$ of the total sequence reads (Figure 2 ). The presence of cyanobacteria, SRB, and

228 SOB was confirmed but at varying abundance. For instance, Cyanobacteria such as

229 Phormidiaceae ranged in proportion between 0 and $3.9 \%$, SRB such as Desulfovibrionaceae

230 between 0.9 and $33.8 \%$, and SOB such as Campylobacteraceae between $15-45 \%$. After

231 subsampling to 7,328 sequences per sample, we found 351 distinct OTUs in the entire dataset

232 (Supplemental Data S1). Species richness (Chao1) and bacterial diversity (Inverse Simpson)

233 were relatively similar between samples, ranging from 98 to 149 OTUs per sample (Table 3 ).

234

\section{3. Black band disease representative bacterial consortia}

236 We compared the sequences from representative bacterial BBD consortium members found in 4

237 coral genera in the southern central Red Sea to sequences obtained from other locations and coral

238 taxa that were affected by BBD on a global scale. Coral disease microbial mat-associated OTUs

239 that represent the three main bacterial consortium members in BBD were successfully identified

240 in our samples:

241 Sulfide oxidizing bacteria (SOB): Beggiatoa sp., a common BBD- SOB member, was absent in

242 our samples, despite microscopic white filaments in the disease lesions which suggested its 
243 presence. Another SOB-consortium member Arcobacter sp. was present in all samples, which

244 has been associated previously with BBD and with white plague disease (WPD)(Sunagawa et al.

245 2009). The SOB-classified OTUs were the most abundant taxa in the dataset. Several OTUs were

246 found to be associated with all coral genera (i.e., Coelastrea, Dipsastraea, Goniastrea, and

247 Platygra) with proportions of up to $22.6 \%$ in all coral samples. (OTU0001, 2, 4, 11, 16: all

248 Arcobacter sp., OTU0010: Sulfurospirillum sp.). These SOB-associated OTUs were found to be

249 similar to those found in different places around the world (e.g., Philippines (Garren et al. 2009)

250 and in the Caribbean including the Netherlands Antilles (Klaus et al. 2011), US Virgin Islands

251 (Cooney et al. 2002), and Puerto Rico (Sunagawa et al. 2009) (Table 4)), where they were

252 associated with varying coral species (Figure 3A).

253 Sulfate-reducing bacteria (SRB): Two abundant OTUs were found to be associated with BBD

254 samples. These OTUs were annotated to Desulfovibrio sp. (OTU0005, OTU0006) with

255 abundance ranges of $0.01-30.7 \%$ in all coral samples. Similar SRB-OTUs were found in the

256 Caribbean (Sekar et al. 2008; Sunagawa et al. 2009) and Japan in different coral species (e.g.,

257 Montipora sp., Orbicella faveolata, and Siderastrea sidereal, Table 4). OTU0005 (Desulfovibrio

258 dechloracetivorans) clustered together with SRB previously found in corals diseased with WPD

259 (Sunagawa et al. 2009) and BBD (Sekar et al. 2006), while OTU0006 (Desulfovibrio

260 marinisediminis) clustered away (Figure 3B), indicating that this is not a typical BBD

261 consortium member.

262 Cyanobacteria: One cyanobacterium (OTU0023, Oscillatoria sp.) was found at proportions of

263 up to $4 \%$ in our coral samples. Cyanobacteria of the same genus ( $99 \%$ sequence similarity) have

264 previously been found in BBD infected Pavona sp. in the GBR (Burger et al., 2016) and from 
265 other regions, e.g. the Caribbean (Casamatta et al. 2012), Hawaii (Aeby et al. 2015b), and Palau 266 (Sussman et al. 2006) (Table 4).

267 Others: Although not belonging to the three main BBD bacterial consortium members,

268 Firmicutes have previously been reported in coral BBD (Barneah et al. 2007; Cooney et al. 2002;

269 Klaus et al. 2011). Members were also found in our dataset at proportions of up to $24.8 \%$

270 (OTU0003, 9, 13, 18). Furthermore, the Firmicutes-associated OTUs in our data were similar to

271 those found in Porites white patch syndrome (PWPS) (Séré et al. 2013) and WPD (Roder et al.

272 2014; Sunagawa et al. 2009) (Table 4).

273 We also retrieved sequences of Vibrio sp. (OTU0015, 29) from our dataset, at proportions of up

274 to $12.8 \%$. These OTU sequences also had a high similarity (98 - 99 \%) to sequences from BBD

275 and WPD (Klaus et al. 2011; Sunagawa et al. 2009) (Table 4).

276 


\section{Discussion}

278 In this study, we report on the distribution and prevalence of coral black band disease in the Red

279 Sea. Our surveys ranged from 19.9 to 24.1 degrees of latitude and confirm the continued

280 presence of BBD in the central Red Sea. Molecular characterization of the bacterial community

281 identified the three main bacterial members of the disease consortium across coral species at a

282 BBD outbreak site in the southern central Red Sea.

283

284

1. Black band disease distribution and prevalence in the Red Sea in comparison to other

285 global sites

286

$\mathrm{BBD}$ is a global disease found in numerous regions, but its prevalence on coral reefs is generally

low compared to other diseases such as white syndromes (WS) (Dinsdale 2002; Edmunds 1991;

Page \& Willis 2006; Willis et al. 2004). The low prevalence recorded in this study is similar to levels reported elsewhere across the globe (Sutherland et al. 2004) with localized outbreaks of BBD also reported in the GBR (Sato et al. 2009), Hawaii (Aeby et al. 2015b), Jamaica (Bruckner

291 \& Bruckner 1997), Venezuela (Rodríguez \& Cróquer 2008), and the Red Sea (Al-Moghrabi 292 2001). In the Red Sea, BBD was first discovered in the 1980s (Antonius 1981) and our study

293 confirms that BBD is a chronic threat to coral reefs in the Red Sea with localized outbreaks 294 continuing to occur.

295 BBD is not a selective disease; multiple species and various levels of severity can affect colonies 296 within and between coral species and across reefs (Bruckner et al. 1997; Dinsdale 2002; Green \& 297 Bruckner 2000; Peters 1993). This was also observed in our study, where multiple species were 298 infected, but with differences in prevalence among coral taxa. At the outbreak site, we found 299 BBD prevalence to be highest in the genus Dipsastraea, which suggests that this genus may be 
300 an important host for BBD in the Red Sea. Our observations match previous reports and shows

301 that this pattern is consistent through time (Antonius 1985). Interestingly, although differential

302 susceptibility to BBD among coral taxa has been found globally, the most vulnerable taxa differ

303 by region. For example, in the Caribbean Montastraea/Orbicella are commonly infected

304 (Bruckner \& Bruckner 1997; Porter et al. 2001), Montipora in Hawaii (Aeby et al. 2015b), and

305 Acropora on the GBR (Page \& Willis 2006). It would be fruitful to examine the underlying 306 defense mechanisms in the different coral taxa that lead to these differences in BBD occurrence.

307

308 2. BBD, climate change, and coral bleaching

309 The occurrence of BBD has been linked to elevated seawater temperatures (Boyett et al. 2007;

310 Kuta \& Richardson 2002; Muller \& van Woesik 2011). The occurrence of a BBD outbreak

311 during a bleaching event in the present study reflects previous reports from the Caribbean, where

312 the positive correlation between bleaching events and BBD incidence was proposed first (Brandt

313 \& McManus 2009; Cróquer \& Weil 2009). For instance, in the Florida Reef Tract, the

314 prevalence of BBD increased from 0 to $6.7 \%$ following bleaching events in 2014 and 2015

315 (Lewis et al. 2017). Also Cróquer \& Weil (2009), found a significant linear correlation between

316 coral bleaching and the prevalence of two other virulent diseases (yellow band disease and white

317 plague) affecting Montastraea/Orbicella species. This further supports a strong relationship

318 between bleaching events and the emergence of some coral diseases on a global scale.

319 Understanding how climate change-related thermal anomalies and coral bleaching drive the

320 emergence and virulence of coral diseases is essential for further research.

321 It has further been suggested that other anthropogenic activities, such as coastal pollution or

322 ocean acidification, contribute to the increase of coral disease incidents (Jackson et al. 2001; 
323 Muller et al. 2017; Rosenberg \& Ben-Haim 2002). The surveyed outbreak area was adjacent to

324 the outflow of a large aquaculture facility, which might have further aggravated the effects of the

325 bleaching event due to increased nutrient availability (Roder et al. 2015; Ziegler et al. 2016). In

326 comparison, other reefs in the Al-Lith area that were further away from the coast displayed

327 similar levels of bleaching, but BBD prevalence stayed at baseline levels in these locations. This

328 suggests that bleaching alone was not the only factor that could have contributed to the BBD

329 outbreak. The synergistic effects of high temperatures and nutrient pollution find further support

330 in the Caribbean where BBD prevalence increased in reef sites with direct sewage input

331 compared to control sites (Sekar et al. 2008) and in the Bahamas, where BBD migration was

332 faster in nutrient-enriched areas (Voss \& Richardson 2006). Further work is needed to directly

333 examine the relationship between bleaching, nutrient stress, and BBD susceptibility.

334

335

3. Bacterial community composition of BBD microbial mats from the southern central

337 Our results verify the presence of the three main consortium members in BBD microbial mats

338 (Cyanobacteria, SOB, SRB) from the southern central Red Sea. We identified Oscillatoria sp. as

339 BBD-associated cyanobacterium, which is similar to the BBD-associated cyanobacteria in other

340 regions of the world (Aeby et al. 2015b; Arotsker et al. 2015; Buerger et al. 2016; Casamatta et

341 al. 2012; Cooney et al. 2002; Frias-Lopez et al. 2003; Gantar et al. 2009; Glas et al. 2010; Meyer

342 et al. 2016; Miller \& Richardson 2011; Rasoulouniriana et al. 2009; Sato et al. 2010; Sussman et

343 al. 2006). However, we retrieved only a low number of cyanobacterial sequences, although

344 cyanobacterial filaments were visually abundant in the sampled microbial mats, which could

345 possibly be related to primer amplification bias. In addition, members of the SOB and SRB 
346 functional groups (Arcobacter sp. and Desulfovibrio sp., respectively) from BBD microbial mats

347 in the southern central Red Sea were similar to those found in other BBD-affected corals

348 worldwide (Barneah et al. 2007; Cooney et al. 2002; Klaus et al. 2011; Sekar et al. 2008). This

349 confirms that BBD-associated bacteria are not restricted to a specific species or region (Barneah

350 et al. 2007; Cooney et al. 2002; Dinsdale 2002; Frias-Lopez et al. 2003). Interestingly, we did

351 observe white filaments within lesions that were morphologically similar to Beggiatoa, a sulfide-

352 oxidizing bacterium associated with BBD in other regions (Cooney et al. 2002; Miller \&

353 Richardson 2011; Sato et al. 2010). However, we found no sequences aligning with Beggiatoa in

354 our study. This suggests that either the white filaments were not Beggiatoa or that the methods

355 used were not adequate to extract and identify Beggiatoa. Aeby et al. (2015b) sequenced

356 Beggiatoa from BBD lesions in Hawaii by first culturing the white filaments from lesions and

357 then using universal bacterial primers $8 \mathrm{~F}$ and $1513 \mathrm{R}$ for sequencing. However, they found that

358 no DNA sequences were available for Beggiatoa found in BBD from other regions even though

359 numerous studies using molecular techniques have been published. Further work is needed to

360 clarify these discrepancies.

361 Beside the three main bacterial consortium members that dominate BBD microbial mats, we

362 detected other bacterial families as part of the BBD consortium. Members of the Firmicutes were

363 abundant in BBD microbial mats, which is consistent with other studies (Arotsker et al. 2016;

364 Arotsker et al. 2009; Barneah et al. 2007; Cooney et al. 2002; Frias-Lopez et al. 2002; Miller \&

365 Richardson 2011; Richardson 2004; Sekar et al. 2008). In addition, we detected the presence of

366 Vibrio species. The pathogenicity of this genus has been documented previously in corals and

367 other marine organisms (Ben-Haim et al. 2003; Harvell et al. 1999; Kushmaro et al. 1996) and

368 more broadly Vibrios have been characterized as opportunistic taxa (Cervino et al. 2004; 
369 Rosenberg \& Falkovitz 2004; Thompson et al. 2004; Ziegler et al. 2016). To date it is unknown

370 whether this group plays a role in the etiology of BBD (Arotsker et al. 2009; Barneah et al. 2007)

371 (Meyer et al. 2016), or whether the high number of Vibrios could be related to seasonal increases

372 in the coral microbiome and coral bleaching (reviewed in Rosenberg \& Koren 2006; Tout et al.

373 2015).

374

\section{Conclusions}

376 Our study represents the first comprehensive assessment of Black Band Disease in the central

377 Red Sea. Elucidation of the bacteria associated with BBD microbial mats of corals at a southern

378 reef site confirms that BBD represents a disease with predictable etiology where the three main

379 bacterial players are globally distributed with regional differences. Notably, our reef survey data, 380 in line with data from other regions, identify BBD as a widespread disease, but as one with low

381 prevalence in comparison to other coral diseases. Additional surveys including other coral

382 diseases as well as pathogen infection experiments with Red Sea corals could further increase

383 our understanding of coral stress tolerance in this understudied coral reef region. Importantly, the

384 prevalence of BBD might increase with ongoing ocean warming and thermal anomalies, as

385 supported by the here-documented disease outbreak coinciding with a thermal anomaly and

386 widespread coral bleaching. The collection of long-term monitoring disease data in the Arabian

387 Seas is important in order to establish baselines, which can then assist in more accurate

388 prediction of disease prevalence and potential impact of climate change on coral communities in 389 this region. 


\section{Acknowledgements}

392 We would like to thank the KAUST Coastal and Marine Resources Core Lab (CMOR) for their 393 assistance and support in field operations and the KAUST Bioscience Core Lab (BCL) for

394 sequencing. We wish to thank Craig Michell (KAUST) for sequence library preparation and 395 Nikolaos Zarokanellos (KAUST) for help with Figure 1.

396 


\section{References}

398

399

400

401

402

403

404

405

406

407

408

409

410

411

412

413

414

415

416

417

418

419

420

421

422

423

424

425

426

427

428

429

430

Aeby GS, Tribollet A, Lasne G, and Work TM. 2015a. Assessing threats from coral and crustose coralline algae disease on the reefs of New Caledonia. Marine and Freshwater Research 34:393-406. 10.1071/MF14151

Aeby GS, Work TM, Runyon CM, Shore-Maggio A, Ushijima B, Videau P, Beurmann S, and Callahan SM. 2015b. First record of black band disease in the Hawaiian archipelago: response, outbreak status, virulence, and a method of treatment. PLOS ONE 10:e0120853. 10.1371/journal.pone. 0120853

Ainsworth T, Kramasky-Winter E, Loya Y, Hoegh-Guldberg O, and Fine M. 2007. Coral disease diagnostics: what's between a plague and a band? Applied and Environmental Microbiology 73:981-992.

Al-Moghrabi S. 2001. Unusual black band disease (BBD) outbreak in the northern tip of the Gulf of Aqaba (Jordan). Coral Reefs 19:330-331. 10.1007/s003380000127

Antonius A. 1973. New observations on coral destruction in reefs. Tenth Meeting of the Association of Island Marine Laboratories of the Caribbean: University of Puerto Rico (Mayaguez).

Antonius A. 1981. Coral reef pathology: a review. 4 International Coral Reef Symposium, Manila (Philippines), 18-22 May 1983.

Antonius A. 1985. Coral Diseases in the Indo-Pacific: A First Record. Marine Ecology 6:197-218. 10.1111/j.1439-0485.1985.tb00322.x

Antonius A. 1988. Distribution and dynamics of coral diseases in the Eastern Red Sea. Proc 6th Int Coral Reef Symp. p 293-298.

Apprill A, McNally S, Parsons R, and Weber L. 2015. Minor revision to V4 region SSU rRNA 806R gene primer greatly increases detection of SAR11 bacterioplankton. Aquatic Microbial Ecology 75:129-137. 10.3354/ame01753

Aronson RB, and Precht WF. 2001. White-band disease and the changing face of Caribbean coral reefs. In: Porter JW, ed. The Ecology and Etiology of Newly Emerging Marine Diseases. Dordrecht: Springer Netherlands, 25-38.

Arotsker L, Kramarsky-Winter E, Ben-Dov E, and Kushmaro A. 2016. Microbial transcriptome profiling of black band disease in a Faviid coral during a seasonal disease peak. Diseases of Aquatic Organisms 118:77-89.

Arotsker L, Kramarsky-Winter E, Ben-Dov E, Siboni N, and Kushmaro A. 2015. Changes in the bacterial community associated with black band disease in a Red Sea coral, Favia sp., in relation to disease phases. Diseases of Aquatic Organisms 116:47-58. 
431

432

433

434

435

436

437

438

439

440

441

442

443

444

445

446

447

448

449

450

451

452

453

454

455

456

457

458

459

460

461

462

463

Arotsker L, Siboni N, Ben-Dov E, Kramarsky-Winter E, Loya Y, and Kushmaro A. 2009. Vibrio sp. as a potentially important member of the Black Band Disease (BBD) consortium in Favia sp. corals. FEMS Microbiology Ecology 70:515-524. 10.1111/j.1574-6941.2009.00770.x

Barneah O, Ben-Dov E, Kramarsky-Winter E, and Kushmaro A. 2007. Characterization of black band disease in Red Sea stony corals. Environmental Microbiology 9:1995-2006. 10.1111/j.14622920.2007.01315.x

Ben-Haim Y, Zicherman-Keren M, and Rosenberg E. 2003. Temperature-Regulated Bleaching and Lysis of the Coral Pocillopora damicornis by the Novel Pathogen Vibrio coralliilyticus. Applied and Environmental Microbiology 69:4236-4242. 10.1128/aem.69.7.4236-4242.2003

Bourne DG, Muirhead A, and Sato Y. 2011. Changes in sulfate-reducing bacterial populations during the onset of black band disease. ISME J 5:559-564. 10.1038/ismej.2010.143

Boyett HV, Bourne DG, and Willis BL. 2007. Elevated temperature and light enhance progression and spread of black band disease on staghorn corals of the Great Barrier Reef. Marine Biology 151:1711-1720. 10.1007/s00227-006-0603-y

Brandt ME, and McManus JW. 2009. Disease incidence is related to bleaching extent in reef-building corals. Ecology 90:2859-2867. 10.1890/08-0445.1

Bruckner. 2002. Priorities for effective management of coral diseases: US Department of Commerce, National Oceanic and Atmospheric Administration, National Marine Fisheries Service.

Bruckner A, and Bruckner R. 1997. The persistence of black band disease in Jamaica: impact on community structure. Proc 8th int coral Reef Symp. p 601-606.

Bruckner AW, Bruckner RJ, and Williams JEH. 1997. Spread of a Black-Band Disease Epizootic Through the Coral Reef System in St. Ann's Bay, Jamaica. Bulletin of Marine Science 61:919928.

Buerger P, Alvarez-Roa C, Weynberg KD, Baekelandt S, and van Oppen MJ. 2016. Genetic, morphological and growth characterisation of a new Roseofilum strain (Oscillatoriales, Cyanobacteria) associated with coral black band disease. PeerJ 4:e2110. 10.7717/peerj.2110

Caporaso JG, Lauber CL, Walters WA, Berg-Lyons D, Huntley J, Fierer N, Owens SM, Betley J, Fraser L, Bauer M, Gormley N, Gilbert JA, Smith G, and Knight R. 2012. Ultra-high-throughput microbial community analysis on the Illumina HiSeq and MiSeq platforms. The ISME journal 6:1621-1624. 10.1038/ismej.2012.8

Carlton RG, and Richardson LL. 1995. Oxygen and sulfide dynamics in a horizontally migrating cyanobacterial mat: Black band disease of corals. FEMS Microbiology Ecology 18:155-162. http://dx.doi.org/10.1016/0168-6496(95)00052-C 
464

465

466

467

468

469

470

471

472

473

474

475

476

477

478

479

480

481

482

483

484

485

486

487

488

489

490

491

492

493

494

495

496

497

Casamatta D, Stanić D, Gantar M, and Richardson LL. 2012. Characterization of Roseofilum reptotaenium (Oscillatoriales, Cyanobacteria) gen. et sp. nov. isolated from Caribbean black band disease. Phycologia 51:489-499. 10.2216/11-10.1

Cervino JM, Hayes RL, Polson SW, Polson SC, Goreau TJ, Martinez RJ, and Smith GW. 2004. Relationship of Vibrio species infection and elevated temperatures to yellow blotch/band disease in Caribbean corals. Applied and Environmental Microbiology 70:6855-6864.

Chao A. 1984. Nonparametric Estimation of the Number of Classes in a Population. Scandinavian Journal of Statistics 11:265-270.

Cooney RP, Pantos O, Tissier MDAL, Barer MR, O'Donnell AG, and Bythell JC. 2002. Characterization of the bacterial consortium associated with black band disease in coral using molecular microbiological techniques. Environmental Microbiology 4:401-413. 10.1046/j.14622920.2002.00308.x

Cróquer A, and Weil E. 2009. Changes in Caribbean coral disease prevalence after the 2005 bleaching event. Diseases of Aquatic Organisms 87:33-43.

Dinsdale E. 2002. Abundance of black-band disease on corals from one location on the Great Barrier Reef: a comparison with abundance in the Caribbean region. Proceedings of the Ninth International Coral Reef Symposium, Bali, 23-27 October 2000. p 1239-1243.

Edgar RC, Haas BJ, Clemente JC, Quince C, and Knight R. 2011. UCHIME improves sensitivity and speed of chimera detection. Bioinformatics 27:2194-2200. 10.1093/bioinformatics/btr381

Edmunds PJ. 1991. Extent and effect of Black Band Disease on a Caribbean reef. Coral Reefs 10:161165. $10.1007 / \mathrm{bf0} 0572175$

Frias-Lopez J, Bonheyo GT, Jin Q, and Fouke BW. 2003. Cyanobacteria associated with coral black band disease in Caribbean and Indo-Pacific reefs. Applied and Environmental Microbiology 69:24092413.

Frias-Lopez J, Klaus JS, Bonheyo GT, and Fouke BW. 2004. Bacterial community associated with black band disease in corals. Applied and Environmental Microbiology 70:5955-5962.

Frias-Lopez J, Zerkle AL, Bonheyo GT, and Fouke BW. 2002. Partitioning of bacterial communities between seawater and healthy, black band diseased, and dead coral surfaces. Applied and Environmental Microbiology 68:2214-2228.

Gantar M, Sekar R, and Richardson LL. 2009. Cyanotoxins from Black Band Disease of Corals and from Other Coral Reef Environments. Microbial Ecology 58:856. 10.1007/s00248-009-9540-x

Garren M, Raymundo L, Guest J, Harvell CD, and Azam F. 2009. Resilience of Coral-Associated Bacterial Communities Exposed to Fish Farm Effluent. PLOS ONE 4:e7319. 10.1371/journal.pone.0007319 
498

499

500

501

502

503

504

505

506

507

508

509

510

511

512

513

514

515

516

517

518

519

520

521

522

523

524

525

526

527

528

529

530

531

532

Glas MS, Motti CA, Negri AP, Sato Y, Froscio S, Humpage AR, Krock B, Cembella A, and Bourne DG. 2010. Cyanotoxins are not implicated in the etiology of coral black band disease outbreaks on Pelorus Island, Great Barrier Reef. FEMS Microbiology Ecology 73:43-54. 10.1111/j.15746941.2010.00874.x

Glas MS, Sato Y, Ulstrup KE, and Bourne DG. 2012. Biogeochemical conditions determine virulence of black band disease in corals. The ISME journal 6:1526-1534. 10.1038/ismej.2012.2

Green EP, and Bruckner AW. 2000. The significance of coral disease epizootiology for coral reef conservation. Biological Conservation 96:347-361. http://dx.doi.org/10.1016/S0006$\underline{3207(00) 00073-2}$

Harvell CD, Kim K, Burkholder JM, Colwell RR, Epstein PR, Grimes DJ, Hofmann EE, Lipp EK, Osterhaus ADME, Overstreet RM, Porter JW, Smith GW, and Vasta GR. 1999. Emerging Marine Diseases--Climate Links and Anthropogenic Factors. Science 285:1505-1510. $10.1126 /$ science. 285.5433 .1505

Harvell D, Altizer S, Cattadori IM, Harrington L, and Weil E. 2009. Climate Change and Wildlife Diseases: When Does the Host Matter the Most? Ecology 90:912-920.

Hoegh-Guldberg O. 2012. Coral Reefs, Climate Change, and Mass Extinction. In: Hannah L, ed. Saving a Million Species: Extinction Risk from Climate Change. Washington, DC: Island Press/Center for Resource Economics, 261-283.

Hughes TP. 1994. Catastrophes, phase shifts, and large-scale degradation of a Caribbean coral reef. Science-AAAS-Weekly Paper Edition 265:1547-1551.

Huse SM, Welch DM, Morrison HG, and Sogin ML. 2010. Ironing out the wrinkles in the rare biosphere through improved OTU clustering. Environmental Microbiology 12:1889-1898. 10.1111/j.14622920.2010.02193.x

Jackson JBC, Kirby MX, Berger WH, Bjorndal KA, Botsford LW, Bourque BJ, Bradbury RH, Cooke R, Erlandson J, Estes JA, Hughes TP, Kidwell S, Lange CB, Lenihan HS, Pandolfi JM, Peterson CH, Steneck RS, Tegner MJ, and Warner RR. 2001. Historical Overfishing and the Recent Collapse of Coastal Ecosystems. Science 293:629-637. 10.1126/science.1059199

Kaczmarsky L. 2006. Coral disease dynamics in the central Philippines. Diseases of Aquatic Organisms 69:9-21.

Katoh K, Rozewicki J, and Yamada KD. 2017. MAFFT online service: multiple sequence alignment, interactive sequence choice and visualization. Briefings in Bioinformatics:bbx108-bbx108. $10.1093 / \mathrm{bib} / \mathrm{bbx} 108$

Klaus JS, Janse I, and Fouke BW. 2011. Coral Black Band Disease Microbial Communities and Genotypic Variability of the Dominant Cyanobacteria (CD1C11). Bulletin of Marine Science 87:795-821. 10.5343/bms.2010.1050 
533

534

535

536

537

538

539

540

541

542

543

544

545

546

547

548

549

550

551

552

553

554

555

556

557

558

559

560

561

562

563

564

565

Kozich JJ, Westcott SL, Baxter NT, Highlander SK, and Schloss PD. 2013. Development of a dual-index sequencing strategy and curation pipeline for analyzing amplicon sequence data on the MiSeq Illumina sequencing platform. Appl Environ Microbiol 79:5112-5120. 10.1128/AEM.01043-13

Kuraku S, Zmasek CM, Nishimura O, and Katoh K. 2013. aLeaves facilitates on-demand exploration of metazoan gene family trees on MAFFT sequence alignment server with enhanced interactivity. Nucleic Acids Research 41:W22-W28. 10.1093/nar/gkt389

Kushmaro A, Loya Y, Fine M, and Rosenberg E. 1996. Bacterial infection and coral bleaching. Nature 380:396-396.

Kuta K, and Richardson L. 2002. Ecological aspects of black band disease of corals: relationships between disease incidence and environmental factors. Coral Reefs 21:393-398. 10.1007/s00338002-0261-6

Kuta KG, and Richardson LL. 1996. Abundance and distribution of black band disease on coral reefs in the northern Florida keys. Coral Reefs 15:219-223. 10.1007/bf01787455

Lewis CL, Neely KL, Richardson LL, and Rodriguez-Lanetty M. 2017. Temporal dynamics of black band disease affecting pillar coral (Dendrogyra cylindrus) following two consecutive hyperthermal events on the Florida Reef Tract. Coral Reefs 36:427-431. 10.1007/s00338-017-1545-1

McDonald D, Price MN, Goodrich J, Nawrocki EP, DeSantis TZ, Probst A, Andersen GL, Knight R, and Hugenholtz P. 2012. An improved Greengenes taxonomy with explicit ranks for ecological and evolutionary analyses of bacteria and archaea. The ISME journal 6:610-618.

McLeod E, Moffitt R, Timmermann A, Salm R, Menviel L, Palmer MJ, Selig ER, Casey KS, and Bruno JF. 2010. Warming Seas in the Coral Triangle: Coral Reef Vulnerability and Management Implications. Coastal Management 38:518-539. 10.1080/08920753.2010.509466

Meyer JL, Gunasekera SP, Scott RM, Paul VJ, and Teplitski M. 2016. Microbiome shifts and the inhibition of quorum sensing by Black Band Disease cyanobacteria. The ISME journal 10:12041216. 10.1038 /ismej.2015.184

Miller AW, and Richardson LL. 2011. A meta-analysis of 16S rRNA gene clone libraries from the polymicrobial black band disease of corals. FEMS Microbiology Ecology 75:231-241. 10.1111/j.1574-6941.2010.00991.x

Miller J, Muller E, Rogers C, Waara R, Atkinson A, Whelan KRT, Patterson M, and Witcher B. 2009. Coral disease following massive bleaching in 2005 causes $60 \%$ decline in coral cover on reefs in the US Virgin Islands. Coral Reefs 28:925. 10.1007/s00338-009-0531-7

Montano S, Strona G, Seveso D, and Galli P. 2012. First report of coral diseases in the Republic of Maldives. Diseases of Aquatic Organisms 101:159-165. 
566

567

568

569

570

571

572

573

574

575

576

577

578

579

580

581

582

583

584

585

586

587

588

589

590

591

592

593

594

595

596

597

598

Montano S, Strona G, Seveso D, and Galli P. 2013. Prevalence, host range, and spatial distribution of black band disease in the Maldivian Archipelago. Diseases of Aquatic Organisms 105:65-74.

Muller EM, Leporacci NM, Macartney KJ, Shea AG, Crane RE, Hall ER, and Ritchie KB. 2017. Low pH reduces the virulence of black band disease on Orbicella faveolata. PLOS ONE 12:e0178869. 10.1371/journal.pone.0178869

Muller EM, and van Woesik R. 2011. Black-band disease dynamics: Prevalence, incidence, and acclimatization to light. Journal of Experimental Marine Biology and Ecology 397:52-57. https://doi.org/10.1016/j.jembe.2010.11.002

Page C, and Willis B. 2006. Distribution, host range and large-scale spatial variability in black band disease prevalence on the Great Barrier Reef, Australia. Diseases of Aquatic Organisms 69:41-51.

Peters EC. 1993. Diseases of other invertebrate phyla: Porifera, cnidaria, ctenophora, annelida, echinodermata. Pathobiology of marine and estuarine organisms:393-449.

Porter JW, Dustan P, Jaap WC, Patterson KL, Kosmynin V, Meier OW, Patterson ME, and Parsons M. 2001. Patterns of spread of coral disease in the Florida Keys. Hydrobiologia 460:1-24. 10.1023/a:1013177617800

Precht WF, Gintert BE, Robbart ML, Fura R, and van Woesik R. 2016. Unprecedented Disease-Related Coral Mortality in Southeastern Florida. Scientific Reports 6:31374. 10.1038/srep31374

Pruesse E, Quast C, Knittel K, Fuchs BM, Ludwig W, Peplies J, and Glöckner FO. 2007. SILVA: a comprehensive online resource for quality checked and aligned ribosomal RNA sequence data compatible with ARB. Nucleic Acids Research 35:7188-7196. 10.1093/nar/gkm864

Randall CJ, and van Woesik R. 2015. Contemporary white-band disease in Caribbean corals driven by climate change. Nature Climate Change 5:375. 10.1038/nclimate2530

https://www.nature.com/articles/nclimate2530\#supplementary-information

Rasoulouniriana D, Siboni N, Ben-Dov E, Kramarsky-Winter E, Loya Y, and Kushmaro A. 2009. Pseudoscillatoria coralii gen. nov., sp. nov., a cyanobacterium associated with coral black band disease (BBD). Diseases of Aquatic Organisms 87:91-96.

Richardson L. 1996. Horizontal and vertical migration patterns of Phorrnidium corallyticum and Beggiatoa spp. associated with black-band disease of corals. Microbial Ecology 32:323-335. $10.1007 / \mathrm{bf} 00183066$

Richardson L, Kuta K, Schnell S, and Carlton R. 1997. Ecology of the black band disease microbial consortium. Proc 8th Int Coral Reef Symp. p 597-600.

Richardson LL. 1998. Coral diseases: what is really known? Trends in Ecology \& Evolution 13:438-443. http://dx.doi.org/10.1016/S0169-5347(98)01460-8 
599

600

601

602

603

604

605

606

607

608

609

610

611

612

613

614

615

616

617

618

619

620

621

622

623

624

625

626

627

628

629

630

Richardson LL. 2004. Black Band Disease. In: Rosenberg E, and Loya Y, eds. Coral Health and Disease. Berlin, Heidelberg: Springer Berlin Heidelberg, 325-336.

Richardson LL, and Kuta KG. 2003. Ecological physiology of the black band disease cyanobacterium Phormidium corallyticum. FEMS Microbiology Ecology 43:287-298. 10.1016/S01686496(03)00025-4

Richardson LL, Miller AW, Broderick E, Kaczmarsky L, Gantar M, Stanić D, and Sekar R. 2009. Sulfide, microcystin, and the etiology of black band disease. Diseases of Aquatic Organisms 87:79-90.

Roder C, Arif C, Bayer T, Aranda M, Daniels C, Shibl A, Chavanich S, and Voolstra CR. 2014. Bacterial profiling of White Plague Disease in a comparative coral species framework. The ISME journal 8:31-39. 10.1038/ismej.2013.127

Roder C, Bayer T, Aranda M, Kruse M, and Voolstra CR. 2015. Microbiome structure of the fungid coral Ctenactis echinata aligns with environmental differences. Molecular Ecology 24:3501-3511. $10.1111 /$ mec. 13251

Rodríguez S, and Cróquer A. 2008. Dynamics of Black Band Disease in a Diploria strigosa population subjected to annual upwelling on the northeastern coast of Venezuela. Coral Reefs 27:381-388. $10.1007 / \mathrm{s} 00338-007-0341-8$

Rosenberg E, and Ben-Haim Y. 2002. Microbial diseases of corals and global warming. Environmental Microbiology 4:318-326. 10.1046/j.1462-2920.2002.00302.x

Rosenberg E, and Falkovitz L. 2004. The Vibrio shiloi/Oculina patagonica Model System of Coral Bleaching. Annual Review of Microbiology 58:143-159. 10.1146/annurev.micro.58.030603.123610

Rosenberg E, and Koren O. 2006. Vibrios in Coral Health and Disease. The Biology of Vibrios: American Society of Microbiology.

Rosenberg E, and Loya Y. 2013. Coral health and disease: Springer Science \& Business Media.

Rützler K, and Santavy DL. 1983. The Black Band Disease of Atlantic Reef Corals. Marine Ecology 4:301-319. 10.1111/j.1439-0485.1983.tb00116.x

Salter SJ, Cox MJ, Turek EM, Calus ST, Cookson WO, Moffatt MF, Turner P, Parkhill J, Loman NJ, and Walker AW. 2014. Reagent and laboratory contamination can critically impact sequence-based microbiome analyses. BMC Biology 12:87. 10.1186/s12915-014-0087-z

Sato Y, Bourne DG, and Willis BL. 2009. Dynamics of seasonal outbreaks of black band disease in an assemblage of $<\mathrm{em}>$ Montipora $<$ em $>$ species at Pelorus Island (Great Barrier Reef, Australia). Proceedings of the Royal Society B: Biological Sciences 276:2795-2803. 10.1098/rspb.2009.0481 
631

632

633

634

635

636

637

638

639

640

641

642

643

644

645

646

647

648

649

650

651

652

653

654

655

656

657

658

659

660

661

662

663

664

Sato Y, Willis BL, and Bourne DG. 2010. Successional changes in bacterial communities during the development of black band disease on the reef coral, Montipora hispida. The ISME journal 4:203.

Schloss PD, Westcott SL, Ryabin T, Hall JR, Hartmann M, Hollister EB, Lesniewski RA, Oakley BB, Parks DH, Robinson CJ, Sahl JW, Stres B, Thallinger GG, Van Horn DJ, and Weber CF. 2009. Introducing mothur: Open-Source, Platform-Independent, Community-Supported Software for Describing and Comparing Microbial Communities. Applied and Environmental Microbiology 75:7537-7541. 10.1128/aem.01541-09

Sekar R, Kaczmarsky LT, and Richardson LL. 2008. Microbial community composition of black band disease on the coral host Siderastrea siderea from three regions of the wider Caribbean. Marine Ecology Progress Series 362:85-98.

Sekar R, Mills DK, Remily ER, Voss JD, and Richardson LL. 2006. Microbial communities in the surface mucopolysaccharide layer and the black band microbial mat of black band-diseased Siderastrea siderea. Applied and Environmental Microbiology 72:5963-5973.

Séré MG, Tortosa P, Chabanet P, Turquet J, Quod J-P, and Schleyer MH. 2013. Bacterial communities associated with Porites white patch syndrome (PWPS) on three Western Indian Ocean (WIO) coral reefs. PLOS ONE 8:e83746.

Simpson EH. 1949. Measurement of diversity. Nature.

Sunagawa S, DeSantis TZ, Piceno YM, Brodie EL, DeSalvo MK, Voolstra CR, Weil E, Andersen GL, and Medina M. 2009. Bacterial diversity and White Plague Disease-associated community changes in the Caribbean coral Montastraea faveolata. ISME J 3:512-521. http://www.nature.com/ismej/journal/v3/n5/suppinfo/ismej2008131s1.html

Sussman M, Bourne D, G, and Willis B, L. 2006. A single cyanobacterial ribotype is associated with both red and black bands on diseased corals from Palau. Diseases of Aquatic Organisms 69:111-118.

Sutherland KP, Porter JW, and Torres C. 2004. Disease and immunity in Caribbean and Indo-Pacific zooxanthellate corals. Marine Ecology Progress Series 266:273-302.

Thompson JR, Randa MA, Marcelino LA, Tomita-Mitchell A, Lim E, and Polz MF. 2004. Diversity and dynamics of a North Atlantic coastal Vibrio community. Applied and Environmental Microbiology 70:4103-4110.

Tout J, Siboni N, Messer LF, Garren M, Stocker R, Webster NS, Ralph PJ, and Seymour JR. 2015. Increased seawater temperature increases the abundance and alters the structure of natural Vibrio populations associated with the coral Pocillopora damicornis. Frontiers in Microbiology 6:432. $10.3389 /$ fmicb.2015.00432

Voss JD, and Richardson LL. 2006. Nutrient enrichment enhances black band disease progression in corals. Coral Reefs 25:569-576. 10.1007/s00338-006-0131-8 
665 Weil E. 2002. Coral disease epizootiology: status and research needs. Coral health and disease:

666

667 developing a national research plan Coral Health and Disease Consortium, Charleston, South Carolina 14.

Weil E. 2004. Coral Reef Diseases in the Wider Caribbean. In: Rosenberg E, and Loya Y, eds. Coral Health and Disease. Berlin, Heidelberg: Springer Berlin Heidelberg, 35-68.

Weil E, Irikawa A, Casareto B, and Suzuki Y. 2012. Extended geographic distribution of several IndoPacific coral reef diseases. Diseases of Aquatic Organisms 98:163-170.

672

673

674

675

676

677

678

679 680

681

682

683
Willis BL, Page CA, and Dinsdale EA. 2004. Coral Disease on the Great Barrier Reef. In: Rosenberg E, and Loya Y, eds. Coral Health and Disease. Berlin, Heidelberg: Springer Berlin Heidelberg, 69104.

Ziegler M, Roik A, Porter A, Zubier K, Mudarris MS, Ormond R, and Voolstra CR. 2016. Coral microbial community dynamics in response to anthropogenic impacts near a major city in the central Red Sea. Marine Pollution Bulletin 105:629-640. http://dx.doi.org/10.1016/j.marpolbul.2015.12.045

Zvuloni A, Artzy-Randrup Y, Stone L, Kramarsky-Winter E, Barkan R, and Loya Y. 2009. SpatioTemporal Transmission Patterns of Black-Band Disease in a Coral Community. PLOS ONE 4:e4993. 10.1371/journal.pone.0004993 


\section{Data accessibility}

685 Sequence data can be accessed through NCBI BioProject accession PRJNA436216 at NCBI

686 (https://www.ncbi.nlm.nih.gov/).

687

688 Author contributions

689 Conceived and designed the study: C.R.V., G.A., M.Z.; conducted surveys/took samples and

690 generated data: all authors; analyzed data and wrote the manuscript: G.H., M.Z., G.A., C.R.V. 
691 Tables

692 Table 1. Survey of black band disease (BBD)-affected coral colonies at 22 reef sites in the 693 central Red Sea. Coral genus counts denote number of BBD-affected colonies.

694

695 Table 2. Survey of black band disease-affected coral genera at an outbreak site in the southern 696 central Red Sea (Al-Lith fringing reef 1, Saudi Arabia).

697

698 Table 3. Summary of sequencing information and alpha diversity measures of bacterial 699 communities associated with black band disease microbial mats from coral colonies in the 700 southern central Red Sea (Al-Lith fringing reef 1, Saudi Arabia). *after subsampling to 7,328 701 sequences. Total number of OTUs: 315.

702

703 Table 4. Summary of bacterial taxa (OTUs) associated with black band disease (BBD) in corals 704 from the southern central Red Sea and comparison with similar taxa from around the world, 705 based on BLAST results (accession number, identity) of the BBD consortium of cyanobacteria, 706 sulfide-oxidizing bacteria (SOB), sulfate-reducing bacteria (SRB), Firmicutes, and Vibrios. 
708 Figures

709 Figure 1. Black band disease survey locations of 22 reef sites along the central Red Sea

710 coast of Saudi Arabia. Survey points marked for Yanbu region (north), Thuwal (central), and

711 Al-Lith (south). Sites without black band diseased coral colonies marked in black, sites with 1 or

7122 diseased colonies in blue, and the site, where a localized outbreak of BBD was observed, is

713 marked in pink.

714

715 Figure 2. Bacterial community composition of black band disease microbial mats from four

716 coral genera (1 colony of Coelastrea, 2 colonies of Dipsastraea, 3 colonies of Goniastrea, and 1

717 colony of Platygyra) from the southern central Red Sea (Al-Lith, Saudi Arabia). Taxonomy

718 stacked column plot on the phylogenetic level of family or to lowest resolved taxonomic level (f

$719=$ family, $\mathrm{o}=$ order, $\mathrm{p}=$ phylum). Each color represents one of the 17 most abundant families.

720 Remaining taxa are grouped under category 'others'.

721

722 Figure 3. Overview and phylogenetic relationship of coral black band disease bacterial

723 consortium members from the southern central Red Sea (Al-Lith, Saudi Arabia) and other

724 regions. (A) Sulfide-oxidizing bacteria (SOB) \& (B) Sulfate-reducing bacteria (SRB).

725 Phylogenetic trees were calculated using the neighbor-joining method, bootstrap values are

726 indicated at the branches. The phylogenetic trees show NCBI accession numbers and sample

727 name, health state of the coral species, host name, and region. Sequences from this study are in

728 bold. The '*' indicates that the bacterial species were not found in coral species. 


\section{Supplemental Information}

730

731 Supplemental Data S1. OTU count table, taxonomic annotation, reference sequence for black

732 band disease (BBD) microbial mat samples from coral colonies collected during a BBD outbreak

733 in the southern central Red Sea.

734 


\section{Table $\mathbf{1}$ (on next page)}

Survey of black band disease (BBD)-affected coral colonies at 22 reef sites in the central Red Sea.

Coral genus counts denote number of BBD-affected colonies. 
1 Table 1. Survey of black band disease (BBD)-affected coral colonies at 22 reef sites in the central

2 Red Sea. Coral genus counts denote number of BBD-affected colonies.

3

\begin{tabular}{|c|c|c|c|c|c|c|c|c|c|c|c|c|c|c|c|c|c|}
\hline Region & Site & $\begin{array}{c}\text { GPS } \\
\text { (latitude, } \\
\text { longitude) }\end{array}$ & $\begin{array}{l}\text { De } \\
\text { pth } \\
\text { (m) }\end{array}$ & $\begin{array}{c}\text { area } \\
\text { colony } \\
\text { count } \\
\text { survey } \\
(\mathrm{m} 2)\end{array}$ & $\begin{array}{c}\text { area } \\
\text { BBD } \\
\text { survey } \\
(\mathbf{m} 2)\end{array}$ & 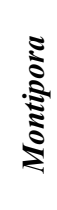 & 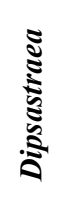 & 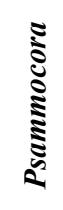 & हूँ & 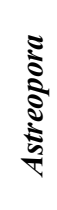 & है & 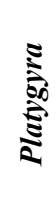 & 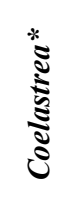 & 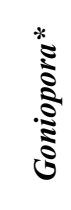 & $\begin{array}{c}\text { Total } \\
\text { no. of } \\
\text { BBD }\end{array}$ & $\begin{array}{c}\text { Total } \\
\text { no. } \\
\text { surve } \\
\text { yed }\end{array}$ & $\begin{array}{c}\text { BBD } \\
\text { preva } \\
\text { lence } \\
(\%)\end{array}$ \\
\hline \multirow[t]{6}{*}{ Yanbu } & $\begin{array}{l}\text { Marker } \\
32\end{array}$ & $\begin{array}{l}23.8664, \\
37.8913\end{array}$ & 4 & 25 & 75.6 & & & & & & & & & & 0 & 726 & 0 \\
\hline & $\begin{array}{l}\text { Marker } \\
35\end{array}$ & $\begin{array}{l}23.8207, \\
37.9350\end{array}$ & 4.6 & 25 & 78 & & & & & & & & & & 0 & 930 & 0 \\
\hline & $\begin{array}{l}\text { Abu } \\
\text { Galaba }\end{array}$ & $\begin{array}{l}23.7891 \\
37.9393\end{array}$ & 3 & 21 & 61.8 & & & & & & & & & & 0 & 848 & 0 \\
\hline & $\begin{array}{l}\text { Fringing } \\
\text { reef } 1\end{array}$ & $\begin{array}{l}24.1362 \\
37.9396\end{array}$ & 5.2 & 25 & 150 & & & & & & & & & & 0 & 1,308 & 0 \\
\hline & $\begin{array}{l}\text { Marker } \\
10\end{array}$ & $\begin{array}{l}24.0189 \\
37.9666\end{array}$ & 4.6 & 25 & 126 & & & & & & & & & & 0 & 1,749 & 0 \\
\hline & $\begin{array}{l}\text { Fringing } \\
\text { reef } 2\end{array}$ & $\begin{array}{l}24.1452, \\
37.9149\end{array}$ & 4.6 & 25 & 150 & & & & & & & & & & 0 & 1,830 & 0 \\
\hline \multirow[t]{9}{*}{ Thuwal } & $\begin{array}{l}\text { Abu } \\
\text { Madafi }\end{array}$ & $\begin{array}{l}22.0766, \\
38.7751\end{array}$ & 4 & 25 & 300 & & 1 & & & & & & & & 1 & 2,184 & 0.05 \\
\hline & Al Fahal & $\begin{array}{l}22.1119 \\
38.8411\end{array}$ & 4.6 & 23.5 & 300 & & & & & & & & & & 0 & 6,000 & 0 \\
\hline & $\begin{array}{l}\text { Al- } \\
\text { Mashpah }\end{array}$ & $\begin{array}{l}22.0772 \\
38.7744\end{array}$ & 6.7 & 25 & 300 & & & & & & & & & & 0 & 4,200 & 0 \\
\hline & $\begin{array}{l}\text { Inner } \\
\text { Fsar }\end{array}$ & $\begin{array}{l}22.2358 \\
39.0304\end{array}$ & 4.6 & 25 & 300 & & & & & 1 & & & & & 1 & 6,852 & 0.01 \\
\hline & Shaab & $\begin{array}{l}22.2012, \\
38.9992\end{array}$ & 4.6 & 25 & 300 & & & & 1 & & & & & & 1 & 5,778 & 0.02 \\
\hline & $\begin{array}{l}\text { Shi'b } \\
\text { Nazar }\end{array}$ & $\begin{array}{l}22.3409 \\
38.8521\end{array}$ & 4.9 & 23.5 & 300 & & & & & & & & & & 0 & 3,294 & 0 \\
\hline & Tahlah & $\begin{array}{l}22.2750 \\
39.0497\end{array}$ & 5.2 & 25 & 300 & & & & & & & & & & 0 & 3,780 & 0 \\
\hline & $\begin{array}{l}\text { Qita al } \\
\text { Kirsh }\end{array}$ & $\begin{array}{l}22.4257 \\
38.9957\end{array}$ & 4.6 & 25 & 300 & & & & & & & & & & 0 & 5,748 & 0 \\
\hline & $\begin{array}{l}\text { Um } \\
\text { Alkthal }\end{array}$ & $\begin{array}{l}22.1653, \\
38.9391\end{array}$ & 7.6 & 25 & 300 & & & & & & & & & & 0 & 5,208 & 0 \\
\hline Jeddah & La Plage & $\begin{array}{l}21.7092, \\
39.0832\end{array}$ & 4.6 & 25 & 300 & & & & & & & 1 & & & 1 & 474 & 0.21 \\
\hline \multirow[t]{6}{*}{ Al-Lith } & Abu Lath & $\begin{array}{l}19.9554 \\
40.1543\end{array}$ & 5.5 & 20 & 240 & & & & & & & & & & 0 & 5,556 & 0 \\
\hline & $\begin{array}{l}\text { South } \\
\text { Reef }\end{array}$ & $\begin{array}{l}19.8985 \\
40.1514\end{array}$ & 3.7 & 20 & 240 & & & & 1 & & & & & & 1 & 3,720 & 0.03 \\
\hline & Al-Lith 3 & $\begin{array}{l}\text { 19.8608, } \\
40.2282\end{array}$ & 5.5 & 20 & 240 & & & & & & & & & & 0 & 4,320 & 0 \\
\hline & $\begin{array}{l}\text { Qita Al } \\
\text { Kirsh }\end{array}$ & $\begin{array}{l}20.1407 \\
40.0931\end{array}$ & 3 & 20 & 240 & & & & & 1 & & & & & 1 & 6,588 & 0.02 \\
\hline & $\begin{array}{l}\text { Fringing } \\
\text { reef } 1\end{array}$ & $\begin{array}{l}20.1732 \\
40.1613\end{array}$ & 4.5 & 20 & 49 & 1 & 15 & 2 & & 1 & 1 & 1 & 1 & 1 & 23 & 1,281 & 1.72 \\
\hline & $\begin{array}{l}\text { Whalesh } \\
\text { ark reef }\end{array}$ & $\begin{array}{l}20.1230 \\
40.2118\end{array}$ & 1.8 & 25 & 150 & & 1 & & 1 & & & & & & 2 & 1,716 & 0.12 \\
\hline
\end{tabular}

$5 *$ *olonies of Coelastrea and Goniopora were only found outside the survey area. 


\section{Table 2 (on next page)}

Survey of black band disease affected coral genera at an outbreak site in the southern central Red Sea (Al-Lith fringing reef 1, Saudi Arabia). 
1 Table 2. Survey of black band disease (BBD)-affected coral genera at an outbreak site in the 2 southern central Red Sea (Al-Lith fringing reef 1, Saudi Arabia).

3

\begin{tabular}{|c|c|c|c|c|}
\hline Coral Species & $\begin{array}{c}\text { No. of coral } \\
\text { colonies / survey } \\
\text { area }\left(20 \mathbf{m}^{2}\right)\end{array}$ & $\begin{array}{l}\% \text { of coral } \\
\text { community }\end{array}$ & $\begin{array}{l}\text { No. of BBD } \\
\text { cases / survey } \\
\text { area }\left(49 \mathrm{~m}^{2}\right)\end{array}$ & $\begin{array}{c}\text { Prevalence } \\
\%\end{array}$ \\
\hline Astreopora & 23 & 4.24 & 1 & 1.8 \\
\hline Coelastrea* & 0 & - & 1 & - \\
\hline Dipsastraea & 101 & 18.63 & 15 & 6.1 \\
\hline Goniopora* & 0 & - & 1 & - \\
\hline Montipora & 11 & 2.03 & 1 & 3.7 \\
\hline Pavona & 5 & 0.92 & 1 & 8.2 \\
\hline Platygyra & 28 & 5.17 & 1 & 1.5 \\
\hline Psammocora & 28 & 5.17 & 2 & 2.9 \\
\hline Other coral genera & 346 & 63.80 & 0 & 0 \\
\hline Total* & 542 & 100 & 23 & 1.7 \\
\hline
\end{tabular}

4

5 *Colonies of Coelastrea and Goniopora were only found outside the survey area and were not counted 6 towards totals. 


\section{Table 3(on next page)}

Summary of sequencing information and alpha diversity measures of bacterial communities associated with black band disease microbial mats from coral colonies in the southern central Red Sea (Al-Lith fringing reef 1, Saudi Arabia).

*after subsampling to 7,328 sequences. Total number of OTUs: 315 . 
1 Table 3. Summary of sequencing information and alpha diversity measures of bacterial 2 communities associated with black band disease microbial mats from coral colonies in the southern 3 central Red Sea (Al-Lith fringing reef 1, Saudi Arabia). *after subsampling to 7,328 sequences. 4 Total number of OTUs: 315.

5

\begin{tabular}{lcrrrr}
\multicolumn{1}{c}{ Sample } & $\begin{array}{c}\text { No. of } \\
\text { sequences }\end{array}$ & $\begin{array}{c}\text { No. of } \\
\text { OTUs* }\end{array}$ & Chao1* & $\begin{array}{c}\text { Inv. } \\
\text { Simpson* }\end{array}$ & $\begin{array}{c}\text { Simpson } \\
\text { evenness* }\end{array}$ \\
\hline Coelastrea & 17,869 & 149 & 203 & 14.10 & 0.095 \\
Dipsastraea 1 & 7,328 & 146 & 240 & 22.33 & 0.153 \\
Dipsastraea 2 & 15,919 & 122 & 160 & 7.71 & 0.063 \\
Goniastrea 1 & 16,201 & 120 & 152 & 8.18 & 0.068 \\
Goniastrea 2 & 15,743 & 113 & 161 & 9.49 & 0.084 \\
Goniastrea 3 & 14,466 & 136 & 159 & 11.57 & 0.085 \\
Platygra & 20,037 & 98 & 125 & 8.50 & 0.087
\end{tabular}

6 


\section{Table 4(on next page)}

Summary of bacterial taxa (OTUs) associated with black band disease (BBD) in corals from the southern central Red Sea and comparison with similar taxa from around the world

Summary of bacterial taxa (OTUs) associated with black band disease (BBD) in corals from the southern central Red Sea and comparison with similar taxa from around the world, based on BLAST results (accession number, identity) of the BBD consortium of cyanobacteria, sulfide-oxidizing bacteria (SOB), sulfate-reducing bacteria (SRB), Firmicutes, and Vibrios. 
1 Table 4. Summary of bacterial taxa (OTUs) associated with black band disease (BBD) in corals 2 from the southern central Red Sea and comparison with similar taxa from around the world, 3 based on BLAST results (accession number, identity) of the BBD consortium of sulfide4 oxidizing bacteria (SOB), sulfate-reducing bacteria (SRB), cyanobacteria, Firmicutes, and 5 Vibrios.

6

\begin{tabular}{|c|c|c|c|c|c|c|c|}
\hline OTU & $\begin{array}{l}\text { Co } \\
\text { unt }\end{array}$ & Taxonomy & $\begin{array}{c}\text { Iden } \\
\text { tity }\end{array}$ & $\begin{array}{l}\text { GenBank } \\
\text { Acc No. }\end{array}$ & Reference & $\begin{array}{l}\text { Health } \\
\text { state }\end{array}$ & Host \& location \\
\hline \multicolumn{8}{|l|}{ SOB } \\
\hline \multirow[t]{3}{*}{ Otu0001 } & 913 & Arcobacter sp. & $99 \%$ & EF089456 & $\begin{array}{l}\text { Barneah et al. } \\
(2007)\end{array}$ & $\mathrm{BBD}$ & $\begin{array}{l}\text { Favites and Dipsastraea, } \\
\text { Red Sea }\end{array}$ \\
\hline & & & & KC527436 & $\begin{array}{l}\text { Roder et al. } \\
(2014)\end{array}$ & WPD & $\begin{array}{l}\text { Pavona duerdeni and } \\
\text { Porites lutea, West } \\
\text { Pacific }\end{array}$ \\
\hline & & & & HM768631 & $\begin{array}{l}\text { Klaus et al. } \\
\text { (2011) }\end{array}$ & $\mathrm{BBD}$ & $\begin{array}{l}\text { Faviidae, Meandrinidae, } \\
\text { Gorgoniidae, Caribbean }\end{array}$ \\
\hline \multirow[t]{3}{*}{ Otu0002 } & 625 & Arcobacter sp. & $99 \%$ & GU319311 & $\begin{array}{l}\text { Meron et al. } \\
(2011)\end{array}$ & Healthy & $\begin{array}{l}\text { Acropora eurystoma, Red } \\
\text { Sea }\end{array}$ \\
\hline & & & & FJ203140 & $\begin{array}{l}\text { Sunagawa et al. } \\
(2009)\end{array}$ & WPD & $\begin{array}{l}\text { Orbicella faveolata, } \\
\text { Caribbean }\end{array}$ \\
\hline & & & & AB235414 & $\begin{array}{l}\text { Yasumoto- } \\
\text { Hirose et al. } \\
(2006)\end{array}$ & - & non coral species \\
\hline \multirow[t]{3}{*}{ Otu0004 } & 336 & Arcobacter sp. & $99 \%$ & KT973145 & $\begin{array}{l}\text { Couradeau et al. } \\
(2017)\end{array}$ & - & non coral species \\
\hline & & & & JF344171 & $\begin{array}{l}\text { Acosta- } \\
\text { González et al. } \\
(2013)\end{array}$ & - & non coral species \\
\hline & & & & FJ949362 & $\begin{array}{l}\text { Suárez-Suárez } \\
\text { et al. (2011) }\end{array}$ & - & non coral species \\
\hline \multirow[t]{3}{*}{ Otu0010 } & 246 & $\begin{array}{l}\text { Sulfurospirillum } \\
\text { sp. }\end{array}$ & $98 \%$ & LC026456 & Unpublished & - & non coral species \\
\hline & & & & AF473976 & $\begin{array}{l}\text { Cooney et al. } \\
(2002)\end{array}$ & $\mathrm{BBD}$ & Faviidae, Caribbean \\
\hline & & & & GU472074 & Unpublished & $\mathrm{BBD}$ & - \\
\hline \multirow[t]{2}{*}{ Otu0011 } & 208 & Arcobacter sp. & $99 \%$ & HM768558 & $\begin{array}{l}\text { Klaus et al. } \\
(2011)\end{array}$ & BBD & $\begin{array}{l}\text { Faviidae, Meandrinidae, } \\
\text { and Gorgoniidae, } \\
\text { Caribbean }\end{array}$ \\
\hline & & & & GQ413587 & $\begin{array}{l}\text { Garren, et al. } \\
(2009)\end{array}$ & - & $\begin{array}{l}\text { Porites cylindrica, West } \\
\text { Pacific }\end{array}$ \\
\hline \multirow[t]{3}{*}{ Otu0016 } & 117 & Arcobacter sp. & $98 \%$ & LC133150 & Unpublished & - & non coral species \\
\hline & & & & HE804002 & Unpublished & - & non coral species \\
\hline & & & & KF185679 & Unpublished & - & non coral species \\
\hline
\end{tabular}




\begin{tabular}{|c|c|c|c|c|c|c|c|}
\hline OTU & $\begin{array}{l}\text { Co } \\
\text { unt }\end{array}$ & Taxonomy & $\begin{array}{c}\text { Iden } \\
\text { tity }\end{array}$ & $\begin{array}{c}\text { GenBank } \\
\text { Acc No. }\end{array}$ & Reference & $\begin{array}{c}\text { Health } \\
\text { state }\end{array}$ & Host \& location \\
\hline \multicolumn{8}{|l|}{ SRB } \\
\hline \multirow[t]{3}{*}{ Otu0005 } & 322 & $\begin{array}{l}\text { Desulfovibrio } \\
\text { dechloracetivor } \\
\text { ans }\end{array}$ & $98 \%$ & AB470955 & Unpublished & Healthy & $\begin{array}{l}\text { Montipora sp., West } \\
\text { Pacific }\end{array}$ \\
\hline & & & & FJ202627 & $\begin{array}{l}\text { Sunagawa et al. } \\
(2009)\end{array}$ & WPD & $\begin{array}{l}\text { Orbicella faveolata, } \\
\text { Caribbean }\end{array}$ \\
\hline & & & & EF123510 & $\begin{array}{l}\text { Sekar et al. } \\
(2008 b)\end{array}$ & $\mathrm{BBD}$ & $\begin{array}{l}\text { Siderastrea siderea, } \\
\text { Caribbean }\end{array}$ \\
\hline \multirow[t]{3}{*}{ Otu0006 } & 294 & $\begin{array}{l}\text { Desulfovibrio } \\
\text { marinisediminis }\end{array}$ & $99 \%$ & MF039931 & Unpublished & - & non coral species \\
\hline & & & & KY771114 & Unpublished & - & non coral species \\
\hline & & & & KT373805 & Unpublished & - & non coral species \\
\hline \multicolumn{8}{|l|}{$\begin{array}{l}\text { Cyanob } \\
\text { acteria }\end{array}$} \\
\hline \multirow[t]{3}{*}{ Otu0023 } & 81 & Oscillatoria sp. & $99 \%$ & KU579394 & $\begin{array}{l}\text { Buerger et al. } \\
(2016)\end{array}$ & $\mathrm{BBD}$ & $\begin{array}{l}\text { Pavona, Great Barrier } \\
\text { Reef }\end{array}$ \\
\hline & & & & HM768593 & $\begin{array}{l}\text { Klaus et al. } \\
\text { (2011) }\end{array}$ & $\mathrm{BBD}$ & $\begin{array}{l}\text { Faviidae, Meandrinidae, } \\
\text { Gorgoniidae,Caribbean }\end{array}$ \\
\hline & & & & GU472422 & Unpublished & $\mathrm{BBD}$ & - \\
\hline \multicolumn{8}{|l|}{$\begin{array}{l}\text { Firmicu } \\
\text { tes }\end{array}$} \\
\hline \multirow[t]{3}{*}{ Otu0003 } & 344 & family JTB215 & $99 \%$ & DQ647593 & Unpublished & - & - \\
\hline & & & & KC527313 & $\begin{array}{l}\text { Roder et al. } \\
\text { (2014) }\end{array}$ & WPD & $\begin{array}{l}\text { Pavona duerdeni and } \\
\text { Porites lutea, Caribbean }\end{array}$ \\
\hline & & & & HM768569 & $\begin{array}{l}\text { Klaus et al. } \\
\text { (2011) }\end{array}$ & $\mathrm{BBD}$ & $\begin{array}{l}\text { Faviidae, Meandrinidae, } \\
\text { Gorgoniidae, Caribbean }\end{array}$ \\
\hline \multirow[t]{2}{*}{ Otu0013 } & 199 & Fusibacter sp. & $99 \%$ & GQ413281 & $\begin{array}{l}\text { Garren et al. } \\
(2009)\end{array}$ & - & $\begin{array}{l}\text { Porites cylindrica, West } \\
\text { Pacific }\end{array}$ \\
\hline & & & & FJ202930 & $\begin{array}{l}\text { Sunagawa et al. } \\
(2009)\end{array}$ & WPD & $\begin{array}{l}\text { Orbicella faveolata, } \\
\text { Caribbean }\end{array}$ \\
\hline \multirow[t]{4}{*}{ Otu0018 } & 112 & Fusibacter sp. & $99 \%$ & KF179748 & $\begin{array}{l}\text { Séré et al. } \\
(2013)\end{array}$ & PWPS & $\begin{array}{l}\text { Porites lutea, Western } \\
\text { Indian Ocean }\end{array}$ \\
\hline & & & & GU472060 & Unpublished & $\mathrm{BBD}$ & - \\
\hline & & & & EU780347 & Unpublished & SWS & Turbinaria mesenterina, \\
\hline & & & & EF089469 & $\begin{array}{l}\text { Barneah et al. } \\
(2007)\end{array}$ & $\mathrm{BBD}$ & $\begin{array}{l}\text { Favites, Dipsastraea, Red } \\
\text { Sea }\end{array}$ \\
\hline \multirow[t]{3}{*}{ Otu0022 } & 82 & $\begin{array}{l}\text { family } \\
\text { Lachnospiraceae }\end{array}$ & $99 \%$ & HM768582 & $\begin{array}{l}\text { Klaus et al. } \\
\text { (2011) }\end{array}$ & $\mathrm{BBD}$ & $\begin{array}{l}\text { Faviidae, Meandrinidae, } \\
\text { Gorgoniidae, Caribbean }\end{array}$ \\
\hline & & & $98 \%$ & AF473930 & $\begin{array}{l}\text { Cooney et al. } \\
(2002)\end{array}$ & $\mathrm{BBD}$ & Faviidae, Caribbean \\
\hline & & & & DQ647585 & Unpublished & - & - \\
\hline \multirow[t]{2}{*}{ Otu0027 } & 62 & Fusibacter sp. & $99 \%$ & JX391361 & Unpublished & - & non coral species \\
\hline & & & & HM768587 & $\begin{array}{l}\text { Klaus et al. } \\
\text { (2011) }\end{array}$ & $\mathrm{BBD}$ & $\begin{array}{l}\text { Faviidae, Meandrinidae, } \\
\text { Gorgoniidae, Caribbean }\end{array}$ \\
\hline
\end{tabular}




\begin{tabular}{|c|c|c|c|c|c|c|c|}
\hline OTU & $\begin{array}{l}\text { Co } \\
\text { unt }\end{array}$ & Taxonomy & $\begin{array}{c}\text { Iden } \\
\text { tity }\end{array}$ & $\begin{array}{l}\text { GenBank } \\
\text { Acc No. }\end{array}$ & Reference & $\begin{array}{l}\text { Health } \\
\text { state }\end{array}$ & Host \& location \\
\hline & & & & FJ202981 & $\begin{array}{l}\text { Sunagawa et al. } \\
(2009)\end{array}$ & WPD & $\begin{array}{l}\text { Orbicella faveolata, } \\
\text { Caribbean }\end{array}$ \\
\hline \multirow[t]{3}{*}{ Otu0031 } & 48 & $W H 1-8 \mathrm{sp}$. & $99 \%$ & KF179804 & $\begin{array}{l}\text { Séré et al. } \\
(2013)\end{array}$ & PWPS & $\begin{array}{l}\text { Porites lutea, Western } \\
\text { Indian Ocean }\end{array}$ \\
\hline & & & & KC527300 & $\begin{array}{l}\text { Roder et al. } \\
\text { (2014) }\end{array}$ & WPD & $\begin{array}{l}\text { Pavona duerdeni and } \\
\text { Porites lutea, West } \\
\text { Pacific }\end{array}$ \\
\hline & & & & FJ203165 & $\begin{array}{l}\text { Sunagawa et al. } \\
(2009)\end{array}$ & WPD & Faviidae, Caribbean \\
\hline \multirow[t]{3}{*}{ Otu0039 } & 30 & $\begin{array}{l}\text { Defluviitalea } \\
\text { saccharophila }\end{array}$ & $99 \%$ & DQ647556 & Unpublished & - & - \\
\hline & & & & FJ202907 & $\begin{array}{l}\text { Sunagawa et al. } \\
(2009)\end{array}$ & WPD & $\begin{array}{l}\text { Orbicella faveolata, } \\
\text { Caribbean }\end{array}$ \\
\hline & & & & AF473925 & $\begin{array}{l}\text { Cooney et al. } \\
(2002)\end{array}$ & BBD & Faviidae, Caribbean \\
\hline \multicolumn{8}{|l|}{$\begin{array}{l}\text { Vibrio } \\
\text { sp. }\end{array}$} \\
\hline Otu0015 & 170 & Vibrio sp. & $99 \%$ & KT974549 & $\begin{array}{l}\text { Couradeau et al. } \\
(2017)\end{array}$ & - & non coral species \\
\hline \multirow{5}{*}{ Otu0029 } & & & $98 \%$ & GU471972 & Unpublished & BBD & - \\
\hline & & & $98 \%$ & MF461384 & Unpublished & - & Eunicella labiata \\
\hline & 56 & $\begin{array}{l}\text { order } \\
\text { Vibrionales }\end{array}$ & $99 \%$ & JQ727003 & $\begin{array}{l}\text { Witt et al. } \\
(2012)\end{array}$ & - & non coral species, GBR \\
\hline & & & & HM768601 & $\begin{array}{l}\text { Klaus et al. } \\
(2011)\end{array}$ & $\mathrm{BBD}$ & $\begin{array}{l}\text { Faviidae, Meandrinidae, } \\
\text { Gorgoniidae, Caribbean }\end{array}$ \\
\hline & & & & FJ202558 & $\begin{array}{l}\text { Sunagawa et al. } \\
(2009)\end{array}$ & WPD & $\begin{array}{l}\text { Orbicella faveolata, } \\
\text { Caribbean }\end{array}$ \\
\hline
\end{tabular}


Figure 1

Black band disease survey locations of 22 reef sites along the central Red Sea coast of Saudi Arabia.

Survey points marked for Yanbu region (north), Thuwal (central), and Al-Lith (south). Sites without black band diseased coral colonies marked in black, sites with 1 or 2 diseased colonies in blue, and the site, where a localized outbreak of BBD was observed, is marked in pink.

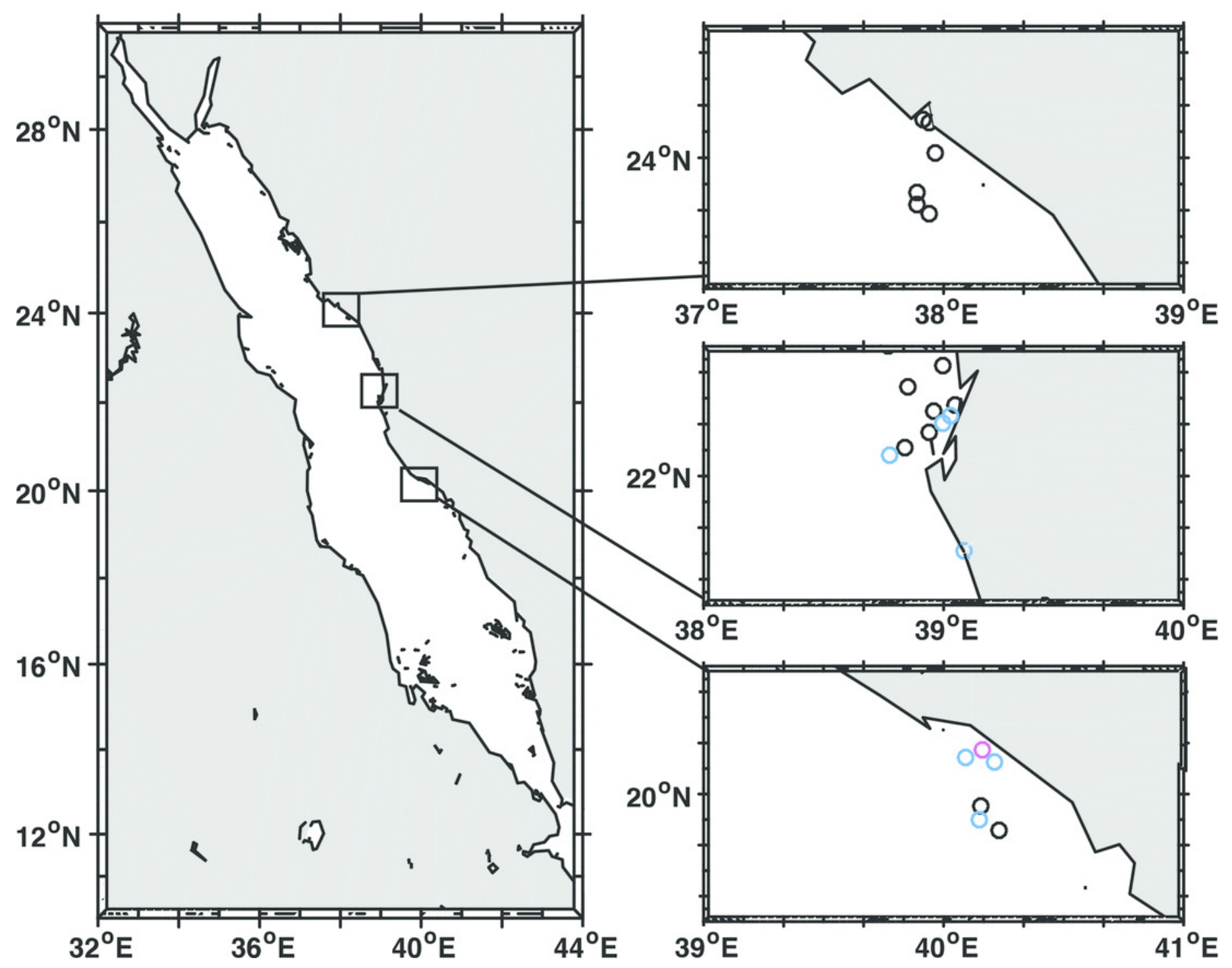




\section{Figure 2}

Bacterial community composition of black band disease microbial mats from four coral genera

( 1 colony of Coelastrea, 2 colonies of Dipsastraea, 3 colonies of Goniastrea, and 1 colony of Platygyra) from the southern central Red Sea (Al-Lith, Saudi Arabia). Taxonomy stacked column plot on the phylogenetic level of family or to lowest resolved taxonomic level $(f=$ family, $0=$ order, $p=$ phylum). Each color represents one of the 17 most abundant families. Remaining taxa are grouped under category 'others'. 


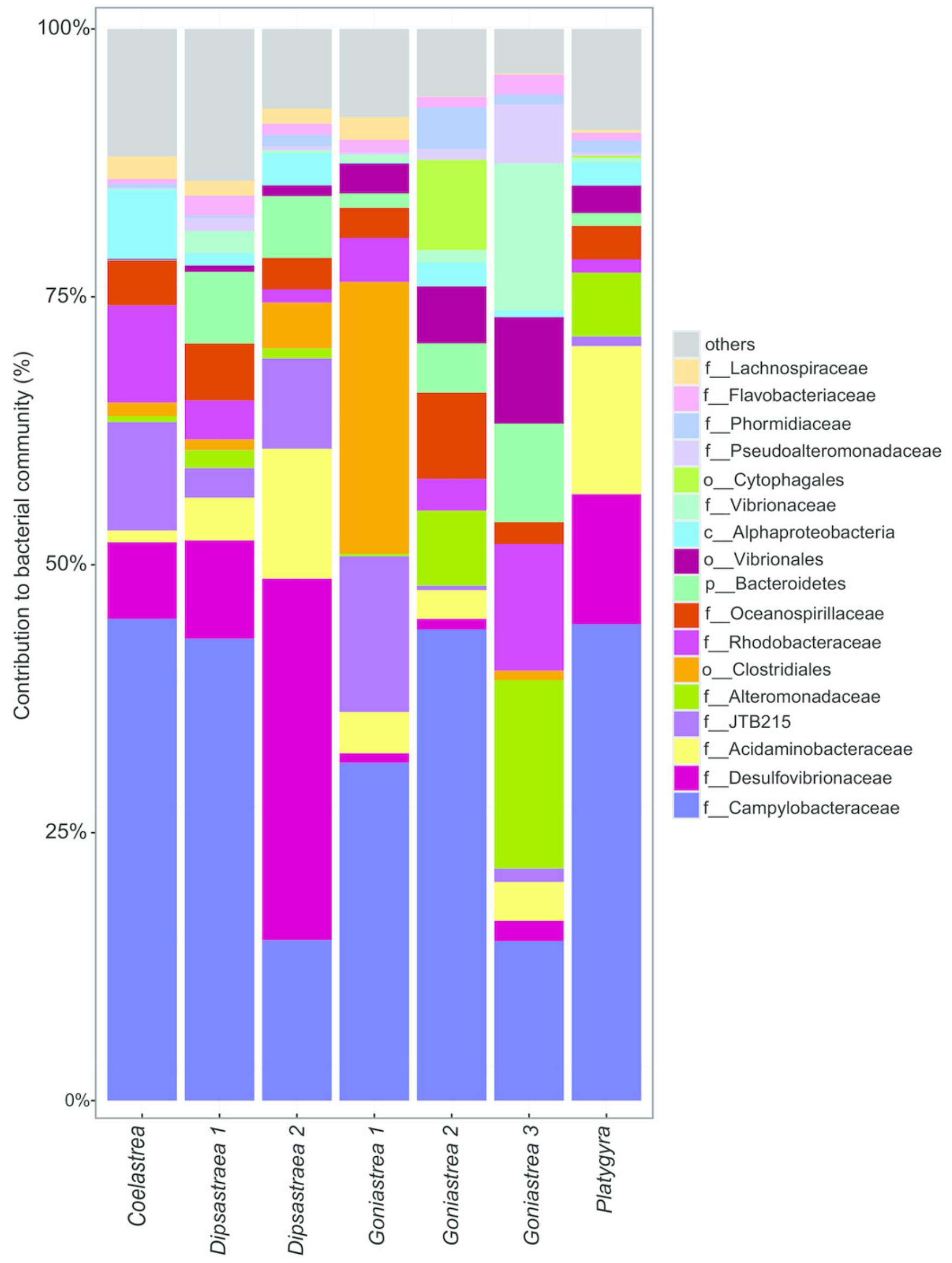




\section{Figure 3}

Overview and phylogenetic relationship of coral black band disease bacterial consortium members from the southern central Red Sea (Al-Lith, Saudi Arabia) and other regions.

(A) Sulfide-oxidizing bacteria (SOB) \& (B) Sulfate-reducing bacteria (SRB). Phylogenetic trees were calculated using the neighbor-joining method, bootstrap values are indicated the branches. The phylogenetic trees show NCBI accession numbers and sample name, health state of the coral species, host name, and region. Sequences from this study are in bold. The ' $*$ ' indicates that the bacterial species were not found in coral species. 

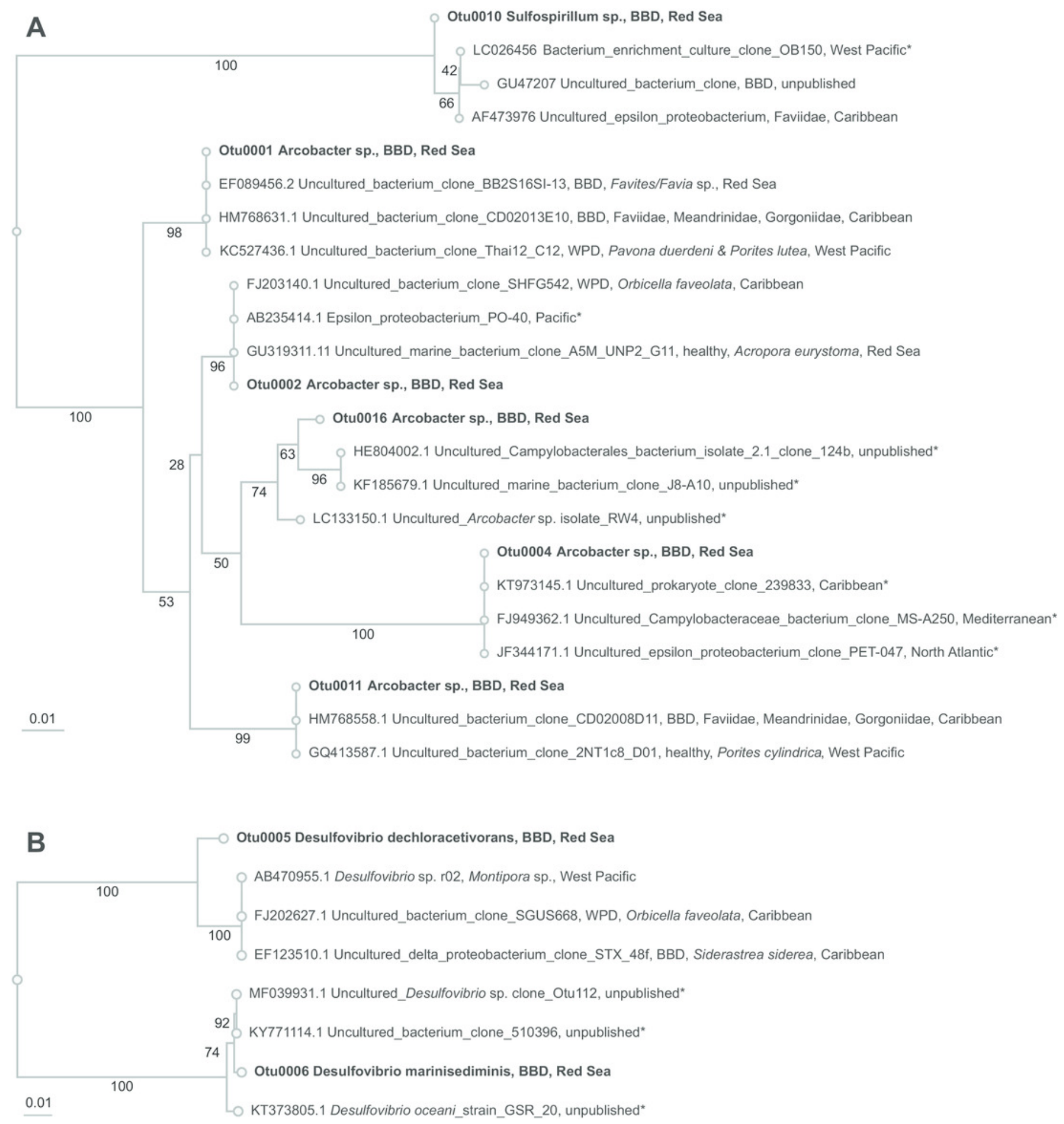